fournal of Medical Genetics (1971). 8, 321.

\title{
Suppression of the Immune Response
}

\author{
JOHN BRADLEY and C. J. ELSON \\ From the Nuffield Unit of Medical Genetics, University of Liverpool
}

The notion of suppressing the immune response emerged with the realization that its expression could have deleterious effects. For example, immune reactions against tissue antigens have been implicated in the pathogenesis of auto-immune diseases. Similarly, the reactions between cytotrophic antibodies of the immunoglobulin E type and antigens such as grass pollens have been established as the initiators of immediate hypersensitivity states. In other circumstances the normal functioning of the immune response may be undesirable. Thus, the penetrating work of Levine and his coworkers showed that $\mathrm{Rh}$ haemolytic disease of the new born was the result of maternal anti-Rh antibodies crossing the placenta and damaging fetal erythrocytes. However, the current interest in immunosuppression derives its principal impetus from the barrier which the immune response imposes on the therapeutic transplantation of tissues and organs between histo-incompatible individuals.

The prime function of the immune response is to reject foreign material such as bacteria, viruses, and tumours. Consequently its overall suppression is fraught with the danger of infection and possibly the failure to reject neoplastic cells unless it can be made selective. The purpose of this article is to review the progress which has been made towards the goal of selective suppression of the immune response. As immunosuppression depends on how the immune response is contrived the one cannot be considered in isolation from the other. Accordingly, immunosuppression is discussed in terms of the current concepts of afferent, central, and efferent phases of the immune response (see Fig. 1). In this review immunosuppression is considered in two parts (1) nonspecific suppression and (2) antigen-specific suppression of the immune response.

Received 4 November 1970.

5-J.M.G.

\section{Immunosuppressive Agents}

The first attempts to suppress the immune response exploited the nonspecific effect of $x$-rays (Salmonsen and Madson, 1898). During the next 60 years the immunosuppressive effect of drugs and other agents was noted occasionally but it was the advent of renal transplantation that pushed the whole problem of altering immunological reactivity to the fore. Initially the agents used were those that had proved of value in cancer chemotherapy, for example $\mathrm{X}$-irradiation and radiomimetic drugs. To these have now been added a great variety of drugs and other agents which have gained their place in the armamentarium primarily because they are good immunosuppressive agents. As the use of these agents became more widespread, it has become apparent that while some agents are good at suppressing one phase of the immune response (eg, presentation of antigen to immunologically competent cells) they have little effect on other phases (eg, antibody synthesis or the expression of cell-mediated immunity). The same holds true for their effect upon the two major divisions of immunological response: some suppress cell-mediated immunity more than antibody-mediated immunity.

Due to the fact that the introduction of many of these agents was empirical, clinical and experimental studies were carried out at the same time. This is reflected in the arrangement of this section of the review. The site(s) of action of immunosuppressive agents has and is being defined, and at the same time they are being used as tools for the dissection and analysis of the immune response. The two will therefore be discussed together. Practically, the essential requirement is for selective immunosuppressive agents, and so it is increasingly important to be aware of the point in the immune response at which they act. However, some agents act at more than one point, and their activity can only be considered in relationship to all 
the points at which they act. Therefore, these agents will be discussed in groups not in relation to the phase(s) of the response they suppress but according to their mode of action or physical state. There have been several exhaustive reviews on the subject of immunosuppression (Gabrielson and Good, 1967; Schwartz, 1968; Sorkin, 1969) and no good purpose would be served by reviewing all the agents used. Instead, emphasis will be placed upon the main action of each group and how its members may be used selectively (see Figs. 1 and 2).

\section{X-Irradiation}

This is one of the oldest methods of immunosuppression, and whole body $\mathrm{X}$-irradiation was used in the early days of renal transplantation. Ionizing radiation stops or reduces the proliferation of cells probably due to damage to nuclear proteins. Even if a cell is not dividing at the time of irradiation the damage produced remains and shows its effect when the cell subsequently attempts to divide (Nettesheim, Makinodan, and Williams, 1967). Maximal depression of the immune response is produced by irradiating the animal a few hours to a few days before antigenic stimulation (Berenbaum, 1962).

In animals, Hume and his coworkers (Hume et al, 1960 ) found it necessary to use $1500 \mathrm{R}$ in order to prevent graft rejection by irradiation alone, but the use of this supralethal dose in man raised the additional problem of marrow grafts to replace the lethally irradiated recipient marrow. Therefore, for a time, sublethal irradiation was used in conjunction with other immunosuppressive agents (Hamburger et al, 1962). Sublethal X-irradiation of the host was used for the first successful kidney allograft in man (Merrill et al, 1960), but thereafter this gave rise to so many problems that it too was

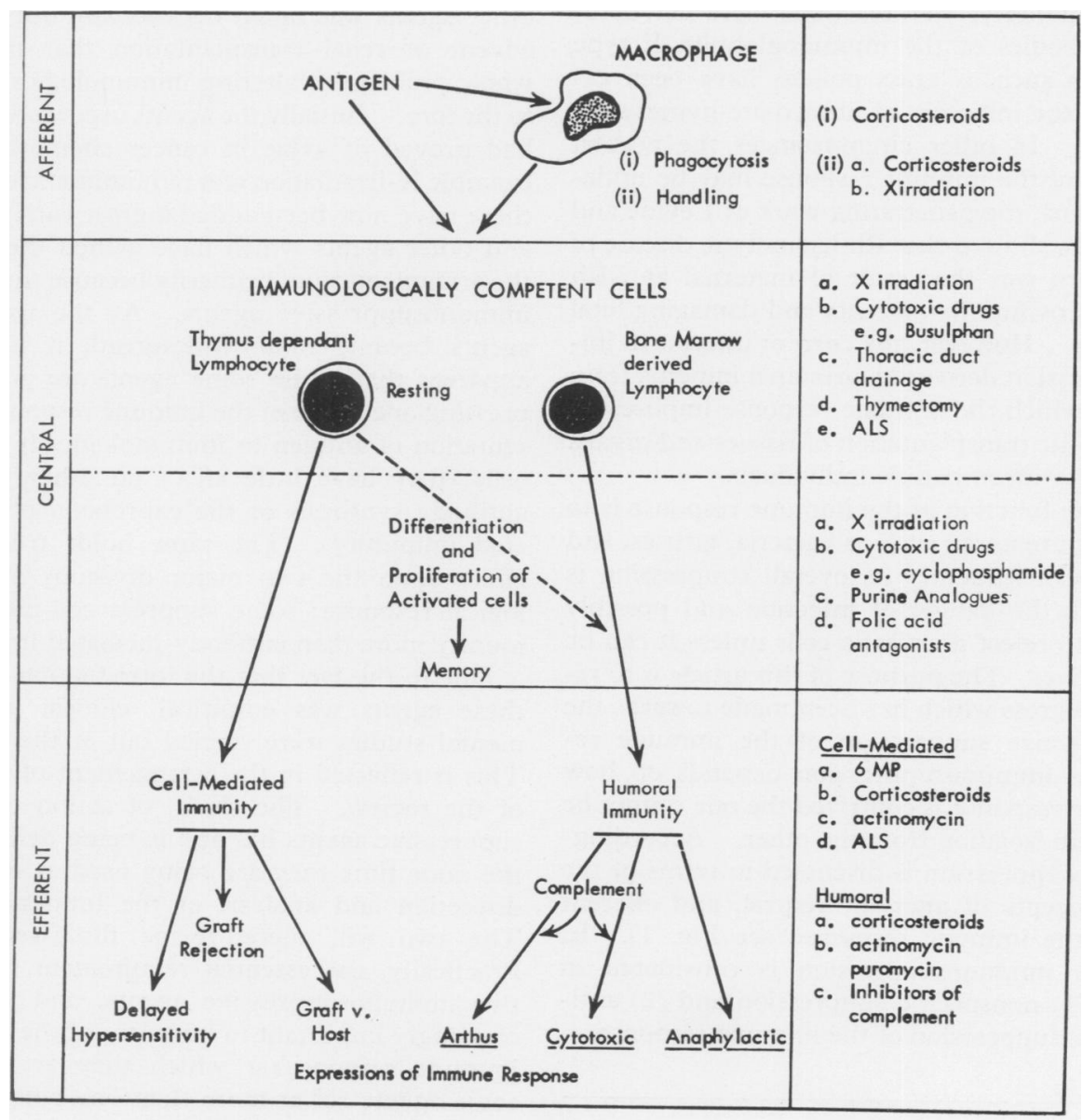

FIG. 1. 


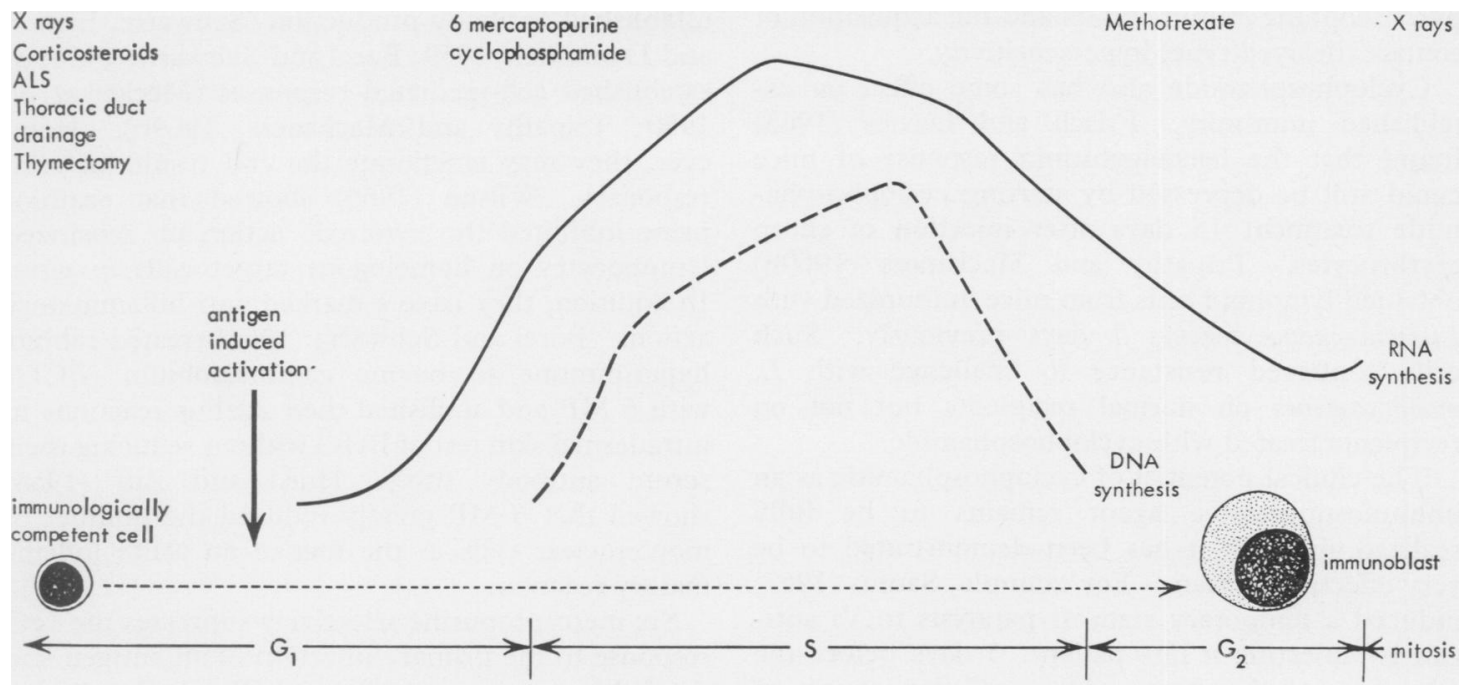

FIG. 2.

discontinued. Irradiation of the potential graft site, transplanted organ, blood, and thoracic duct has also been utilized as a means of immunosuppression. Hume et al (1964) gave local X-irradiation to the site of the grafted kidney during the first week after transplantation. Data from the Transplant Registry indicates that locally irradiated kidneys have a greater one year survival than those not irradiated (Gleason and Murray, 1967).

\section{Alkylating, Cytotoxic, or Radiomimetic Drugs}

This group of drugs which share the ability to alkylate amino, sulphohydroxal, and sulphide groups, includes the nitrogen and sulphur mustards, triethylenemelamine, and busulphan. Since there is a multiplicity of such groups in biological materials it is difficult to discern their primary site of action, but they have been shown to block cell progression at the DNA synthetic (S) phase and the premitotic $\mathrm{G}_{2}$ resting phase (Palm and Liss, 1966; Wheeler, 1962 and 1967).

The immunosuppressive effects of alkylating agents were first noted nearly 50 years ago. Hektoen and Corper (1921) found that mustard gas suppressed the precipitin and haemolysin response of dogs and rabbits to sheep and rat blood. The term 'radiomimetic' was used to characterize the group until a few years ago because their mode of action appeared to resemble that of $x$-rays. Some members of the group eg, busulphan do produce maximal suppression of the immune response if given before the antigen (cf, $x$-rays, p. 322), but this is not so for most members of the group (Berenbaum, 1962).
Cyclophosphamide, a transport form of nitrogen mustard, is a member of the latter subgroup. It has attracted much attention recently because of its proven immunosuppressive efficacy in man and animals. It acts predominantly on the central phase of the immune response. There is no evidence that it affects the access of antigen to immunologically competent cells (afferent limb), and it does not affect the functional capacity of macrophages (see Tripathy and Mackaness, 1969a). The immunosuppressive effectiveness of cyclophosphamide depends on the timing of drug treatment relative to antigen injection. In rodents pretreatment with cyclophosphamide suppressed the haemaglutinin response to sheep erythrocytes (Santos and Owens, 1964 and 1965; Dietrich, 1966). This is probably because one of its effects is to produce a decrease in the number of immunologically competent cells. However, cyclophosphamide produces its maximum immunosuppressive effect when given 24 to 48 hours after antigen injection (Frisch and Davies, 1965; Dietrich, 1966). This is not merely due to its antimitotic activity as other antimitotic agents (eg, colchicine) have little effect at this time (Sterzl, 1961 ; Dietrich, 1966). Possibly the principal effect of cyclophosphamide is to impair the metabolism of antigen-activated lymphocytes thus preventing their differentiation and replication. This is consistent with Turk's morphological analysis (1964) of the cellular events in the draining lymph node during the development of contact sensitivity to oxazalone in the guinea pig. Cyclophosphamide was found to block the production of large 
pyroninophilic immunoblasts and the acquisition of contact (delayed type) hypersensitivity.

Cyclophosphamide also has some effect on established immunity. Frisch and Davies (1965) found that the haemagglutinin response of mice could still be depressed by starting cyclophosphamide treatment 15 days after injection of sheep erythrocytes. Tripathy and Mackaness (1969b) obtained lymphoid cells from mice immunized with Listeria monocytogenes 7 days previously. Such cells conferred resistance to challenge with $L$. monocytogenes on normal recipients but not on recipients treated with cyclophosphamide.

The clinical potential of cyclophosphamide as an immunosuppressive agent remains to be fully realized although it has been demonstrated to be very effective in man. For example, Santos (1967) induced a temporary state or paralysis to Vi antigen by injecting it into patients 3 days before the first dose of the drug. After a 7-day course of cyclophosphamide the patients were given a challenge injection of $\mathrm{Vi}$ antigen and a first injection of Pasteurella tularensis. They responded to Past. tularensis but not $\mathrm{Vi}$ antigen.

\section{Antimetabolites}

Purine Analogues. Six mercaptopurine (6MP) was intended to be a competitive inhibitor of hypoxanthine. It proved to be a powerful antimetabolite (Elion, Hitchings, and Vanderwerff, 1951) and modifications of the parent compound such as its imadazole derivative, azathioprine (Imuran) and its congener 6-thioguanine, were later synthesized. The principal effect of these compounds is to block the synthesis and interconversion of purine nucleotides (Hampton, 1963) which are required for nucleic acid synthesis. There is evidence that the immunosuppressive selectivity of these drugs lies in their differential action on the early central phase of the immune response. They produce maximal suppression of antibody formation if given between 12 and 72 hours of antigen injection (Sterzl, 1960; Frisch and Davies, 1962; Chanmougan and Schwartz, 1966). In contrast, pretreatment with 6 mercaptopurine or azathioprine may enhance antibody production (Chanmougan and Schwartz, 1966; Swanson and Schwartz, 1967). Schwartz (1968) has suggested that this is due to the release of nucleic acids which have an adjuvant-like effect. Not all facets of the immune response may be enhanced in this way. Enhanced rejection of renal allografts has not been observed when azathioprine was administered to patients before transplantation (Starzl, 1964).

Six MP and azathioprine have little effect on established antibody production (Schwartz, Eisner, and Dameshek, 1959; Borel and Schwartz, 1964) or established cell-mediated responses (Meeker et al, 1960; Tripathy and Mackaness, 1969b). However, they may ameliorate the end results of such responses. Wilson (1965) showed that azathioprine inhibited the cytotoxic action of sensitized lymphocytes on homologous target cells in vitro. In addition, they have a marked anti-inflammatory action. Borel and Schwartz (1964) treated rabbits hyperimmune to bovine gammaglobulin (BGG) with $6 \mathrm{MP}$ and abolished their Arthus reactions to intradermal skin test of BGG without reducing their serum antibody titres. Hurd and Ziff (1968) showed that $6 \mathrm{MP}$ greatly reduced the number of mononuclear cells at the foci of an acute inflammatory reaction.

Six mercaptopurine selectively supresses the IgG response to the primary injection of an antigen and the IgM response is prolonged (Borel, Fauconnet, and Miescher, 1965). This property is not unique to 6 mercaptopurine. It occurs following treatment with cyclophosphamide and methotrexate (Blinkoff, 1966; Santos and Owens, 1966). This indicates that there is some difference between the train of cellular events leading to an IgM response and that leading to an IgG response. The development of cellular immunity may also be selectively inhibited by $6 \mathrm{MP}$. Borel and Schwartz (1964) gave a 4-day course of the drug to rabbits injected with BGG which prevented the appearance of delayed type hypersensitivity but not that of antibody production.

Clinically, purine antagonists have been the group of drugs most frequently used as immunosuppressive agents after corticosteroids. In transplantation azathioprine has proved of great value. It has replaced $6 \mathrm{MP}$ as the 'backbone' of immunosuppressive regimes as it seems to be less toxic for the gut epithelium than $6 \mathrm{MP}$. The auto-immune group of diseases have been treated with corticosteroids, but in those cases where they have failed to produce a remission purine antagonists have been used. Such conditions as auto-immune haemolytic anaemia (Corley, Lessner, and Larsen, 1966), chronic hepatitis (Page, Good, and Pollara, 1969), glomerulonephritis and the nephrotic syndrome (Merrill, 1962; White and Cameron, 1966; Piel et al, 1969), ulcerative colitis (Corley et al, 1966), rheumatoid arthritis, systemic lupus erythematosus (Piel et al, 1969), polyarteritis nodosa, and multiple sclerosis (Corley et al, 1966) have all been treated with these drugs. Assessment of their value has been difficult because frequently corticosteroids are given at the same time. In addition, there is a high 
frequency of undesirable side effects eg, susceptibility to infections and toxic effect on the bone marrow and liver.

Folic Acid Antagonists. Aminopterin and amethopterin (methotrexate) inhibit the action of dihydrofolic acid reductase and thereby prevent the conversion of folic acid to folinic acid (Bertino, 1963; Werkheiser, 1963). Folinic acid is necessary as a carrier of single carbon units in the synthesis of purines, thymidylate and some amino acids. Methotrexate in vitro inhibits DNA synthesis. Lymphocyte cultures did not respond to antigenic stimulation by transforming into blast cells and incorporating tritiated thymidine in the presence of methotrexate (Caron, 1967). This contrasts with the effect of methotrexate on the cellular events in the draining lymph nodes during the development of contact sensitivity in the guinea pig. Methotrexate did not block the development of large pyroninophilic immunoblasts (cf, cyclophosphamide, p. 323), nor did it prevent their uptake in vivo of tritiated thymidine. It did, however, reduce their uptake of tritiated leucine and tritiated uridine (Turk and Stone, 1963; Turk, 1964; Diengdoh and Turk, 1966). These findings suggest that methotrexate in vivo decreases RNA rather than DNA synthesis.

Methotrexate causes maximum suppression of antibody formation in rodents if injected about 2 days after antigen (Berenbaum, 1962; Santos and Owens, 1964). It inhibits the acquisition of cellular immunity (Friedman, Buckler, and Baron, 1961 ; Turk, 1964) and interferes with its development. Lymphoid cells from animals sensitized with antigen 5 to 7 days previously, were susceptible to the action of methotrexate as judged by the partial failure of methotrexate-treated recipients to exhibit cellular immunity (Friedman and Buckler, 1963; Tripathy and Mackaness, 1969b). Similarly, Prichard and Hayes (1961) prevented caseation of tuberculous granulomas with methotrexate. However, Turk (1964) found that methotrexate-treated recipients exhibited contact sensitivity to oxazalone shortly after injection of lymphoid cells from donors sensitized to oxazalone 6 weeks earlier. Thus, methotrexate does not prevent sensitized cells from exerting their effect.

In man, methotrexate has been found to suppress antibody formation against a variety of antigens (Santos, Owens, and Sensenbrenner, 1964; Hersh et al, 1965). Unfortunately methotrexate is fairly toxic in both man and animals and this has limited its use. Berenbaum and Brown (1965) have found a novel means of circumventing this problem.
They gave folinic acid to methotrexate-treated mice which had been injected with TAB vaccine 2 days earlier. The mice did not succumb to the lethal side effects of methotrexate yet their anti-TAB antibody response was suppressed. By spacing the 'rescue' dose of folinic acid they showed that methotrexate required only 8 hours to exert its immunosuppressive effect.

\section{Corticosteroids}

Corticosteroids have been used extensively to suppress the immune response over the past 30 years. Each phase of the immune response appears to be susceptible to their influence. This feature distinguishes them from other immunosuppressive agents.

Cornwell (1953) found that the uptake of particulate material was impaired in animals treated with corticosteroids but this was not corroborated by other workers (Gell and Hinde, 1953). This disparity may be due to the different dosages used. In rats the clearance rate of carbon particles was reduced only if large doses of cortisone were given (Wiener et al, 1967). The ability of macrophages to break down ingested material such as tubercule bacilli and heterologous erythrocytes is reduced in corticosteroid-treated rabbits (Kass, Kendrick, and Finland, 1953; Lurie, 1960). Thus, corticosteroids may limit the access of antigen to immunologically competent cells.

Dukor and Dietrich (1968) studied the effects of a single injection of cortisone acetate on the haemagglutinin response of mice to sheep erythrocytes. The haemagglutinin response was maximally suppressed by giving the drug 12 hours before antigen injection. They suggested that this was due to the action of corticosteroids on thymus derived lymphocytes. Thymus derived lymphocytes are known to be essential participants in the immune response of mice to sheep erythrocytes (Miller and Mitchell, 1968; Mitchell and Miller, 1968), and they are particularly sensitive to damage by corticosteroids (Schrek and Batra, 1966).

Corticosteroids do not induce the type of paralysis associated with the use of cyclophosphamide and 6 mercaptopurine (Dukor and Dietrich, 1968) (see sections on p. 324 and 333). This suggests that they do not damage proliferating, antigen-activated cells. This is consistent with the effects of corticosteroids on the kinetics of antibody production. Maximal suppression of antibody levels does not occur until some time (15-45 days) after antigen injection (Dukor and Dietrich, 1968).

Corticosteroids can inhibit the efferent limb of the 
immune response. Ambrose (1964) found that high concentration $(0.1 \mathrm{mg} / \mathrm{ml}$ culture medium) reduced antibody production by isolated lymph node fragments from rabbits immunized against bovine serum, albumin, and diphtheria toxoid. Rosenau and Moon (1962) showed that hydrocortisone inhibited the cytolytic action of sensitized lymphocytes on homologous target cells. Corticosteroids may also interfere with the expression of the immune response by their anti-inflammatory action. Gell and Hinde (1951) studied the effect of cortisone on the histological appearance of an acute foci of inflammation in rabbits. Cortisone inhibited vasodilatation and reduced the mononuclear cell infiltrate. Similar changes were observed in the tuberculin reaction of sensitized rabbits.

Clinically, corticosteroids have been used as immunosuppressive agents in auto-immune disease and transplantation. In most auto-immune diseases they have justifiably proved to be the agent of choice (for review see Parker and Vavra, 1969). They are usually included in the immunosuppressive regimes given to patients with surviving renal grafts as they can inhibit incipient rejection (for review see Mannick and Egdahl, 1968).

\section{Antibiotics}

Actinomycins. The actinomycins act by binding the guanine residue of DNA thus blocking the synthesis of DNA-dependent RNA. In vitro they inhibit antibody synthesis by lymph node fragments taken from rabbits immunized against a variety of antigens (Uhr, 1963; Smiley, Heard, and Ziff, 1964) and prevent transformation of phytohaemagglutinin stimulated lymphocytes (Hirschhorn et al, 1963). This suggests that these processes involve DNA-dependent RNA synthesis.

The actinomycins have not been used much in vivo because of their toxicity. Nevertheless, actinomycin $C$ has successfully been employed to treat rejection crises in renal transplantation. It reverses incipient or even advanced rejection (Merrill, 1968).

Puromycin. This antibiotic is structurally similar to part of soluble RNA and inhibits aminoacid transfer from soluble RNA to ribosomal protein. It is not an effective immunosuppressive agent in vivo within the limits imposed by its toxicity but in vitro it has been found to be a very potent inhibitor of ongoing antibody responses. Smiley et al (1964) cultured spleen and lymph node fragments of rabbits hyperimmunized to BSA after recent restimulation with BSA, and found that a concentration of $10^{-3}$ and $10^{-4} \mathrm{M}$ puromycin inhibited synthesis of anti-BSA.

Mitomycin C. In low concentrations this antibiotic depolymerizes DNA and inhibits its replication. At higher concentrations it also affects RNA and protein synthesis (Sekiguchi and Takagi, 1960). Its toxicity has limited its usefulness in vivo. When used in canine renal transplantation, the mean survival of the grafts was doubled at the expense of severe toxic symptoms including bleeding (Otte and Grosjean, 1964). Mitomycin $\mathrm{C}$ has been used successfully as a means of avoiding a graft versus host reaction in mice. Maternal lymphocytes were treated in vitro with mitomycin $\mathrm{C}$ and injected into $\mathrm{C}$-irradiated $\mathrm{F} 1$ hybrids. The donor cells did not react against their new host although they were able to react to other antigens (Lemmel and Good, 1969).

\section{Inhibitors of Complement}

The F1 hybrids of New Zealand black and white mice spontaneously develop glomerulonephritis. This is produced by the deposition of DNA-antibody complexes in the glomerulus and the activation of the complement sequence. Polymorphonuclear leucocytes accumulate at the site of deposition in response to the chemotactic factors liberated by the activated complement sequence and destruction of renal glomeruli ensues. This eventually leads to the animals' death. Investigation of animals that are deficient in one of the components of the complement system has revealed how important this system is in the pathogenesis of the disease. In the Ajax strain of mice ( $\mathrm{C}^{\prime} 3$ deficient) DNA-antibody complexes form and are deposited in the glomeruli but no renal damage occurs (Lambert and Dixon, 1968). Attempts have therefore been made to produce complement deficiency as a means of suppressing complement-mediated immunological reactions. Flexner and Noguchi in 1903 inactivated serum complement with cobra venom. The site of inactivation has recently been identified as C'3. The active cobra venom factor (molecular weight 140,000 ) reacts with an unidentified gammaglobulin to produce a complex which degrades C'3 (Müller-Eberhard, 1968). It partially inhibits the development of acute nephrotoxic nephritis and immediate (Arthus) type hypersensitivity reactions. Unfortunately the catabolic rate of the cobra venom factor is high, the half life being less than 2 days. If other agents can be found with similar sites of action and slower catabolic rates it would be possible to selectively inhibit complement-mediated antibody effects. 


\section{Alpha Globulins}

Kamrin (1959) and Mowbray (1963) have reported that alpha-globulin-rich fractions of normal human, bovine, rabbit, and rodent sera inhibit cellular and humoral immune responses. Other workers have failed to confirm these observations (Spiegelberg and Weigle, 1964; Pullar, James, and Naysmith, 1968). However, a number of factors critically affect the immunosuppressive properties of these fractions. For example, the material has to be injected intravenously 10 to 20 hours before the injection of antigen in order to be effective in mice. Moreover, inactive preparations were rendered active by storage at -20 or $+4^{\circ} \mathrm{C}$ (Mowbray and Hargrave, 1966). A similar pattern of immunosuppressive activity has been found with ribonuclease chemically complexed to proteins such as bovine serum albumin (Mowbray and Scholand, 1966). This led Mowbray and Hargrave to consider that the immunosuppressive activity of the alpha-globulin-rich fractions was due to ribonuclease since ribonuclease was associated with these fractions. Other workers have not been able to associate the immunosuppressive activity of alpha-globulin-rich preparations with ribonuclease activity (Cooperband et al, 1969; Mannick and Schmid, 1967), and this raises the possibility that alpha-globulin-rich preparations contain more than one immunosuppressive factor (see Kamrin, 1969).

\section{Lymphocyte Depletion}

Thoracic Duct Cannulation. Depleting rats of their lymphocytes by long term drainage of the thoracic duct has been shown to prolong the survival of skin grafts (McGregor and Gowans, 1964) and to impair their primary, but not secondary, response to sheep red cells and tetanus toxoid (Gowans et al, 1962). The technique was soon applied as an adjunct to immunosuppressive therapy in human renal transplanatation (Franksson, 1964; Tilney and Murray, 1967), and it appeared to reduce the number of rejection crises. Recently Sarles and his coworkers (Sarles et al, 1970) reported the use of thoracic duct drainage as the initial means of immunosuppression in human renal transplantation. The donors and recipients were matched for $\mathrm{ABO}$ blood group only. Thoracic duct drainage of recipients commenced before transplantation, a marked lymphocytopenia developed and the paracortical zones of lymph nodes and white pulp of the spleen (thymic-dependent areas) became depleted of lymphocytes. These morphological changes were in keeping with the alteration produced in immunological reactivity; delayed hypersensitivity reactions to a number of antigens disappeared whilst immunoglobulin levels remained constant.

Thymectomy. Following the fascinating work on the role of the thymus in the development and maintenance of the immunological system (see Miller and Osoba, 1967), thymectomy was used to suppress immunity. However, the effects of thymectomy in adults are not seen immediately because of a pre-existing circulating pool of thymicderived immunologically competent cells. Thus thymectomy has often been used in conjunction with an agent specifically aimed at depleting this circulating pool. For example, if mice are thymectomized and subjected to $X$-irradiation they will not develop antibodies in response to an injection of sheep erythrocytes (Miller, Doak, and Cross, 1963). Starzl and his associates (Starzl et al, 1970) have recently reported the results of thymectomy in 24 of a series of 46 consecutive human renal transplants. The patients were followed for $3 \frac{1}{2}-5$ years. There was no clinical evidence that the patients with thymectomy had an early or late advantage in terms of survival, but Starzl et al (1970) believe that further studies are worth while.

Splenectomy. It is difficult to understand the rationale for using splenectomy as a means of immunosuppression. The proliferation of normal lymphoid tissue is directly related to the amount of stimulation by antigens. The spleen contains about one third of the total lymphoid tissue of the body, and splenectomy merely makes more antigen available to stimulate the remaining lymphoid tissue.

\section{Antilymphocyte Serum and Globulin (ALS,ALG)}

There is something appealing to both the modern clinician and research worker in the elegance and refinement of inactivating the lymphocytes involved in the immunological response by an injection of antilymphocyte serum (ALS) or antilymphocyte globulin (ALG). The idea is not new. At the turn of the century, Metchnikoff (1899) produced an antileucocyte serum by injecting rat spleen or lymph node cells into rabbits and noted leucoagglutination and leucocytoxicity. However, it is only recently that the concomitant alterations in immunological reactivity following ALS administration have attracted attention: delayed hypersensitivity reactions to tuberculin and dinitrochlorobenzene were inhibited (Inderbitzin, 1956), and skin graft rejection retarded (Waksman, Arbouys, and Arnason, 1961). The ability of this agent to prolong significantly the survival of skin allografts in 
rats across a marked histo-incompatibility barrier (Woodruff and Anderson, 1963) drew attention to its possible value in transplantation. Much work has been done on it since then (see James, 1967a; James, 1969; Sell, 1969).

The Effects of ALS in vivo. Antilymphocyte serum will sometimes produce a leucopenia (Chew and Lawrence, 1937; Cruickshank, 1941) and if the lymph nodes are examined histologically depletion of lymphocytes is seen particularly in the thymic dependent paracortical areas (Turk and Willoughby, 1967). Most workers now agree that immunosuppressive activity of ALS cannot be directly related to the degree of leucopenia produced by its administration. More recent work has shown that ALS exerts its effect primarily by reducing the number of circulating long lived, thymic-influenced lymphocytes. However the total number of lymphocytes in the peripheral blood may or may not decrease according to whether there is a compensatory increase in the number of short lived lymphocytes (Nagaya and Sieker, 1967; Denman and Frenkel, 1968).

It is now well established that ALS can prevent the development of cellular immunity, eg, by suppressing graft versus host disease and delaying the acute rejection of allografts (Levey and Medawar, 1966 and 1967; Brent, Courtney, and Gowland, 1967). Moreover, the suppressive efficacy of ALS is little influenced by the antigenic disparity between donor and recipient; human skin grafts have been maintained on ALS-treated mice for over 2 months (Lance and Medawar, 1968; Lance, Levey, and Medawar, 1969). The suppression by ALS of a primary antibody response has been observed in several species (Monaco et al, 1966; James, 1967b). To be fully effective ALS has to be administered at the time of, or before the antigenic challenge (Russell and Monaco, 1967), and the antilymphocyte titre should be high. Antilymphocyte serum has the ability to modify established cell-mediated immune responses but has little effect on established humoral responses. It delays the rejection of second set skin allografts (Levey and Medawar, 1966; Monaco et al, 1966; Lance, 1968), but fails to produce a marked suppression of secondary antibody responses (James and Jubb, 1967; Lance, 1968). In parallel studies of cell-mediated and humoral immunity Lance and Batchelor (1968) further demonstrated the differential susceptibility of these two major facets of the immune response to ALS. At a dosage of ALS, which completely inhibited the rejection of skin grafts across a major histo-compatibility (H2) difference in mice, the primary antibody response to a number of antigens still occurred.

The Effects of ALS in vitro. Antilymphocyte serum produces lysis of lymphocytes when complement is present (Besredka, 1900). If complement is not present leuco-agglutination occurs. ALS also causes the transformation of lymphocytes into lymphoblasts (Holt, Ling, and Stanworth, 1966), inhibition of the lymphocyte mediated destruction of cells in culture (Biberfeld, Holm, and Perlmann, 1969) and suppression of the mixed lymphocyte reaction (Schwartz, Tyler, and Everett, 1968).

Mechanism of Action of ALS. There are various theories as to how ALS exerts these immunosuppressive effects in vivo and in vitro.

The preferential cytoxic effect. The leucopenic effect of ALS was noted seventy years ago, but more recently it was noted that there was no constant relationship between this and the degree of immunosuppression. As mentioned earlier, it may be that this is due to the fact that there is a selective depletion of thymic derived long lived recirculating lymphocytes (Denman and Frenkel, 1968) and that the numbers of short lived lymphocytes may or may not increase to compensate for this. Lance (1970) suggests that lymphocytes coated with ALS are either lysed due to the direct action of complement or phagocytosed by the reticulo-endothelial cells of the liver. As the cells are removed from the blood they are replaced by other members of the recirculating pool which in turn are coated and removed by lysis or phagocytosis. The majority of the pool of recirculating cells are long lived, slowly regenerating lymphocytes and, therefore, after ALS therapy ceases the immunosuppressive action continues until the long lived lymphocyte pool is restored to its normal size.

The sterile activation of lymphocytes was proposed because of the known ability of ALS to produce proliferation of lymphocytes both in vitro and in vivo. The activation of all potentially antigen-reactive ('virgin') cells would thus cause a temporary absence of any cells competent to react to the presence of a new antigen.

The lymphocyte blindfolding theory (Levey and Medawar, 1966) postulated that ALS may bind to receptors on the lymphocytes surface and, by coating or 'blindfolding' it, prevent it from reacting with an antigen. The presence of heterologous IgG has been detected on the surface of lymphocytes after incubating them in ALG (Brent et al, 1967; Woodruff, Reid, and James, 1967). 
The anti-thymus factor in ALS has been suggested as the cause of its potency. The fact that thymectomy potentiates the effect of ALS and that antisera prepared against thymocyte membrane fraction produce the most consistent immunosuppression (Lance, Ford, and Ruszkiewicz, 1968) lends credence to this.

It may be that all these proposed mechanisms contribute to the effects of ALS but the importance of its ability to destroy antigen reactive thymusdependent cells in vivo is evident.

In man ALS had not yet produced such impressive results (Monaco, Wood, and Russell, 1967; Russell, 1968) as in laboratory animals. However, Starzl et al (1970) now report that the one-year survival of patients with transplanted kidneys has increased to $90 \%$ from $50-60 \%$ with the use of heterologous ALG in their immunosuppressive therapy. Thus it seems likely that ALG will be eventually of great clinical value.

\section{Antigen-specific Suppression of the Immune Response}

A number of methods by which immunological reactivity to a specific antigen can be suppressed have been described in experimental animals. Some understanding of the limitations of these methods is required before they can be applied clinically. This section concentrates on the mechanisms underlying the production of various states of antigen-specific immunological suppression so as to provide a basis for considering how they may be exploited.

\section{Antibody-mediated Suppression of the Immune Response}

The suppressive effect of passive antibody on the immune responses to the corresponding antigen was documented by the turn of the century. Dongern (1906) and Sachs (1906) observed that the haemolysin response of rabbits to ox erythocytes complexed with rabbit antiserum to ox erythrocytes was far less than rabbits injected with ox erythrocytes alone. Similarly, Smith (1909) found that guinea pigs did not become immunized to diphtheria toxin by injection of diphtheria toxin mixed with an excess of antitoxin. Since these discoveries there have been considerable efforts to establish how passive antibody exerts its effect.

Effect of Passive Antibody on Afferent Limb of Immune Response. In some systems there is evidence that suppression of antibody formation against one antigenic determinant on a molecule does not suppress antibody formation against a second determinant. For example, Pollack et al (1968) prevented anti- $\mathrm{Hg}^{\mathrm{A}}$ antibody production in rabbits injected with $\mathrm{Hg}^{\mathrm{A}} \mathrm{Hg}^{\mathrm{F}}$ rabbit erythrocytes and anti- $\mathrm{Hg}^{\mathrm{A}}$ iso-antibody, but provoked anti- $\mathrm{Hg}^{\mathrm{F}}$ antibody formation. This phenomenon may be extensive since similar findings have been reported by other workers using a variety of antigens (Olitzki, 1935; Möller, 1965; Brody, Walker, and Siskind, 1967; Dixon, Jacot-Guillarmod, and McConahey, 1967). The simplest explanation of these findings is that passive antibody exerts its effect by covering the corresponding antigenic determinants and hence preventing them stimulating the appropriate antigen sensitive cell. If this theory is correct then it would be expected that the ability of antibody to suppress would be related to its concentration and affinity. In a definitive study, Walker and Siskind (1968) assessed the effect of changes in the affinity of anti-haptenbovine gamma-globulin antibody on its ability to suppress the response to haptenbovine gamma-globulin in rabbits. They found that high affinity antibody can cause suppression at much lower concentrations than low affinity antibody. This they argue is consistent with the theory that antigen binding is involved in suppression since it follows from the law of mass action that the amount of antigen bound at any given concentration of antibody is a function of the affinity of the antibody. This finding may also resolve the controversy which has arisen over the question of whether or not antibody of the IgM type is capable of causing suppression. Some workers have found that $\operatorname{IgM}$ antibody can suppress a primary immune response (Rowley and Fitch, 1964; Pearlman, 1967; Pollock et al, 1968), whereas others have been unable to demonstrate suppression with $\operatorname{IgM}$ antibody (Henry and Jerne, 1968). This divergence may be explained by the differences in the affinity of the various IgM preparations.

The importance of the interaction between antibody and specific antigenic determinants is also shown by the finding that antibody fragments containing the antigen-binding site are effective in bringing about suppression (Tao and Uhr, 1966; Cerottini, McConahey, and Dixon, 1969). Thus, Cerottini et al (1969) found that the $\mathrm{F}\left(\mathrm{ab}^{\prime}\right)_{2}$ and $\mathrm{Fab}$ fragments of anti-haemocyanin antibody suppressed anti-haemocyanin antibody formation in rabbits. However, there is evidence that the $\mathrm{Fc}_{\mathrm{c}}$ piece plays some part in the suppressive effect of antibody. Sinclair (1969) has found that the ability of anti-sheep erythrocyte serum to inhibit priming to sheep erythrocytes in mice is lost after removal of the Fc piece by pepsin digestion. The 
work of Ivanyi (1970) may also be relevant. He found that the fraction of anti-HSA (human serum albumin), which was active in suppressing the immune response of chickens to HSA, was antibody of the cytophilic type. The cytophilic properties of such antibody are known to be dependent on the integrity of the Fc portion of the molecule (Berken and Benacerraf, 1966).

There are studies in which it has been noted that administration of passive antibody against one antigenic determinant on a molecule suppresses antibody formation against all its antigenic determinants, ie, passive antibodies act at the level of the entire antigenic molecule. Henney and Ishizaka (1968) found that passive administration of antibody against the Fc portion of human IgG suppressed both anti-Fab and anti-Fc antibody formation in the guinea pig. They gave the passive antibody in the footpad in the form of a complex with human IgG emulsified in Freund's complete adjuvant. In this experiment it is difficult to envisage how antibody could suppress the immune response by merely covering the corresponding antigenic determinant particularly as this phenomenon persisted when antigen was given in fourfold excess. On the contrary it seems likely that the passive antibodies acted by preventing antigen reaching the neighbourhood of the appropriate antigen-sensitive cells.

A situation in which there is an apparent lack of specificity of suppression is the interference with Rh-iso-immunization due to ABO incompatibility. Pollack et al (1968) and Pollack, Gorman, and Freda (1969) have argued that since lysed erythrocytes are less immunogenic than unlysed erythrocytes, then complement fixing antibodies against one antigenic determinant on an erythrocyte could lyse the erythrocyte and as a consequence antibody formation against all the antigenic determinants on the erythrocyte would be suppressed. Thus they suggested that the mechanism by which $\mathrm{ABO}$ incompatibility interferes with $R h$ iso-immunization may be due to lysis of Rh positive erythrocytes by complement fixing anti-A and anti-B. However, Stern, Goodman, and Berger (1961) showed that $\mathrm{Rh}^{-}$men injected with $\mathrm{ARH}^{+}$erythrocytes coated in vitro with anti-A did develop anti-Rh antibody. Stern (1969) has also investigated an analogous phenomenon in rats. He found that the anti-isophile antibody response to challenge with sheep erythrocytes (containing both heterophile and isophile antigens) was almost completely suppressed by pretreatment of rats with heterophile antigen alone. This suppression of anti-isophile antibody was not brought about by passive administration of small amounts of anti-heterophile antibody 2 hours before injection of sheep erythrocytes. Stern has taken these results to indicate that the mechanism by which $\mathrm{ABO}$ incompatibility interferes with $\mathrm{Rh}$ iso-immunization is not exclusively humoral.

Central Effect of Passive Antibody. It has been suggested that passive antibody has a direct effect on immunologically competent cells so that they are prevented from synthesizing antibody following stimulation by the corresponding antigen (Rowley and Fitch, 1967). This theory was based on the finding that the exposure of normal rat spleen cells in vitro to anti-sheep erythrocyte serum suppressed their early haemolysin response to sheep erythrocytes in X-irradiated recipients (Rowley and Fitch, 1964). There is an alternative interpretation of this finding. It is now known that the macrophage is an essential participant in the initiation of the immune response to some antigens eg, sheep erythrocytes in mice (Pierce, 1969a; Shortman et al, 1970). Using a system in vitro, Pierce (1969b) studied the suppressive effect of anti-sheep erythrocyte serum on purified populations of mouse spleen cells. He exposed separated (macrophage free) splenic lymphoid cells to anti-sheep erythrocyte serum and, after reconstituting them with splenic macrophages, tested their ability to respond to sheep erythrocytes. Their response was not impaired. In contrast, separated lymphoid cells were presô vented from responding to sheep erythrocytes by reconstituting them with macrophages which had been incubated with anti-sheep erythrocyte serum. The specificity of this phenomenon was shown by the finding that such reconstituted lymphoid cells responded to burro erythrocytes. These findings render it unlikely that passive antibody has a direct effect on lymphoid cells but rather that the antigenic stimulus is blocked at the macrophagedependent phase of the response. It would be premature to conclude that this phenomenon of neutralization of antigen in the macrophage occurs with all antigens since the initiation of the immune response to some antigens eg, haemocyanin, appears to be macrophage-independent (Unanue and Askonas, 1967).

Rowley and Fitch's proposal (1967) has recently been resuscitated by Feldmann and Diener (1970). They incubated isolated normal mouse spleen cells for 1 to 100 hours with mixtures of antigen (polymerized flagellin of Salmonella adelaide or sheep erythrocytes) and antibody. Such cells were found to be partially (50-95\%) unresponsive to an optimal antigenic challenge in vitro. In addition, such cells were found unable to respond to antigenic challenge after transfer to $\mathrm{X}$-irradiated syngeneic re- 
cipients as judged by serological and cellular assays. In both situations spleen cells treated with antibody alone gave a normal response. These results were taken as evidence that an in-vitro effect of antibodymediated suppression occurred 'centrally' on immunologically competent cells exposed to antigen. The significance of these findings to the situation in vivo is uncertain. A number of workers have found that lymphoid cells from intact animals suppressed by the mediation of passive antibody are competent to initiate an immune response against the corresponding antigen after transfer to X-irradiated syngeneic recipients (Möller, 1964; McCullagh and Gowans, 1967; Wigzell, 1967). Furthermore, if the degree of suppression found in vitro by Feldman and Diener occurred in intact animals then animals in which primary immunization was suppressed by antibody should remain unresponsive to subsequent antigen challenge. Generally, such animals do respond to a second antigenic stimulation although their response may not be a typical primary response (Mason, Robinson, and Christensen, 1955; Nossal, 1957; Uhr and Baumann, 1961; Sinclair, 1969). On the other hand, it has been noted that suppression of the immune response of rats to sheep erythrocytes by simultaneous administration of antisheep erythrocyte serum can be maintained by weekly injections of small doses of sheep erythrocytes alone (Neiders, Rowley, and Fitch, 1962). Possibly in this situation passive antibody facilitates the induction of antigen-mediated suppression of the immune response.

Effect of Passive Antibody on Cell-mediated Immunity. The effect of passive antibody is not limited to the suppression of humoral responses. The growth of allogeneic tumour cells was found to be enhanced by treatment in vitro with the corresponding allo-antibody. That this effect is not merely due to inhibition of the recipients transplantation immunity was shown by the finding that untreated tumour cells injected at a different site in the same recipient were rejected efficiently (Möller, 1964). The alternative explanation is that antibody blocked the efferent limb of the immune response, hindering graft destruction by the recipient's sensitized cells. This hypothesis is substantiated by Möller's observation (1965) that treatment of allogeneic tumour cells with antibody conferred resistance to the cytotoxic effect in vitro of sensitized lymphoid cells.

It seems likely that in some situations passive antibody does prevent the initiation of cell mediated responses. Axelrad (1968) has shown that the delayed hypersensitivity response of rats to sheep erythrocytes emulsified in Freund's complete adjuvant is reduced by prior administration of passive antibody. Rats given a second sensitizing injection of sheep erythrocytes exhibited maximal delayed hypersensitivity despite having high titres of circulating antibody. This renders it unlikely that the detection of delayed hypersensitivity was blocked by antibody. However, passive antibody does not always block the induction of delayed hypersensitivity. Uhr and Baumann (1961) failed to suppress delayed skin reactivity to diphtheria toxoid by injections of diphtheria toxoid-antitoxin complexes although the humoral response was prevented.

In summary, the suppressive efficacy of passive antibody is apparently dependent on its affinity and concentration, but may also be influenced by its biological properties. From a practical viewpoint it appears that high affinity antibody of the IgG type has the highest suppressive efficiency. These observations are consistent with the hypothesis that passive antibody exerts its effect by interfering with the access of antigen to antigen-sensitive cells, either by covering the corresponding antigenic determinants and rendering them sterically unavailable to antigen-sensitive cells or by diverting antigen away from the anatomical area of antigen-sensitive cells. If antibody only affects the 'afferent' limb of the immune response then the corresponding immunologically competent cells will be still available to respond to subsequent antigenic stimulation. In this event the use of passive antibody is limited to the prevention of an immune response rather than its permanent suppression. However, it appears that in some situations passive antibody may facilitate the induction of an antigenmediated defect in the corresponding immunologically competent cells.

\section{Antigen-mediated Suppression}

The state of specific immunological suppression induced by exposure to a particular antigen has been termed 'paralysis', 'tolerance', and 'unresponsiveness'. The term 'paralysis' was coined to describe the phenomenon of specific immunological non-reactivity induced by the administration of large amounts of pneumoccal polysaccharide to adult animals (Felton and Bailey, 1926; Felton and Ottinger, 1942). 'Tolerance' was originally used in connexion with the failure of an animal to reject a homograft (see Burnet, 1941), and was later used to denote the phenomenon of specific immunological suppression induced by limited exposure to an antigen in perinatal life (Billingham, Brent, and Medawar, 1953). 'Unresponsiveness' was applied 
to the specific suppression of the immune response induced by exposure to non-living antigens (Smith, 1961). It has been found that lymphoid cells from animals rendered tolerant to skin grafts (Argyris, 1963) and unresponsive to Shigella antigens and bovine serum albumin (Friedmann, 1962; Dietrich and Weigle, 1964) are unable to respond to the corresponding antigenic stimulation when transferred to X-irradiated syngeneic recipients. Similarly, Brooke and Karnovsky (1961) found that lymphoid cells from paralysed mice in contrast to those from immunized mice, were unable to protect allogeneic recipients from a lethal dose of Pneumococci. These findings suggest that tolerance, unresponsiveness, and paralysis are basically similar phenomena in that there is deletion of some of, or all the corresponding immunologically competent cells (a central defect). Thus the terms are often used synonymously. However, it is now clear that not all facets of the immune response are eliminated in antigen-suppressed animals. For example, Voisin, Kinsky, and Maillard (1968) injected neonatal CBA mice with A strain spleen cells. Such animals produced haemagglutinating antibodies against $\mathrm{A}$ strain histo-incompatible antigens despite the fact that they were unable to reject A strain skin grafts.

In this review, tolerance will be used in its original connection (see above) and paralysis to imply that the immune response is suppressed by a 'central' defect in the corresponding immunologically competent cells.

Recovery from Paralysis. Generally, persistence of paralysis is associated with the continued presence of the corresponding antigen. For example, some adult $\mathrm{A}$ strain mice which had been inoculated in utero with viable tissues from CBA mice, accepted skin grafts from CBA mice more or less permanently (Billingham, Brent, and Medawar, 1956). The tissues of such mice were shown to contain cells of donor origin (Billingham and Brent, 1959). Similarly, the duration of paralysis to bovine serum albumin (BSA) in rabbits was extended by giving additional injection of BSA to paralysed rabbits (Smith, 1961). One explanation of this is that the inactivated immunologically competent cells require the corresponding antigen for their continued inactivation. However, in the mouse, recovery for paralysis to BSA was complete within 3 months (Mitchison, 1965). It seems unlikely that this was solely due to loss of antigen since the rate of degradation of extracellular antigen did not vary with the age of mice whereas the duration of paralysis increased with the age of mice. Simi- larly, in rabbits paralysis induced by neonatal administration of heterologous serum proteins persisted for up to 2 years, long after the paralysing antigen was cleared (Humphrey, 1964). The alternative explanation is that the corresponding immunologically competent cells are irreversibly inactivated during the induction of paralysis and that recovery involves the recruitment of new cells. This possibility is substantiated by the finding that recovery from paralysis is minimal in thymectomized adult animals (Claman and Talmage, 1963; Taylor, 1964; Aisenberg and Davies, 1968). The presence of the thymus is now known to be necessary for the acquisition of responsiveness by the stem cells from which immunologically competent cells originate (Miller and Osoba, 1967).

Mechanism of Paralysis. The mechanism by which immunologically competent cells are paralysed by antigen is not yet clear. Fishman and his coworkers (Fishman, van Rood, and Adler, 1965; Adler, Fishman, and Dray, 1966) have presented evidence that phagocytosis of an antigen is an essential step in the initiation of the primary immune response. Although the exact mechanism is still in doubt (Askonas and Rhodes, 1965; Harris and Cramp, 1968) it seems likely that the induction of an IgM antibody response to some antigens involves the sequential action of macrophages and lymphocytes (Pierce, 1969a; Shortman et al, 1970). As a corollary to this hypothesis it has been proposed that the induction of paralysis is due to the failure of macrophages to phagocytose and degrade antigen thus allowing it to reach lymphocytes intact (Frei, Benacerraf, and Thorbecke, 1965). This proposition was based on the finding that adult animals could be readily paralysed by the injections of heterologous serum proteins from which the supposedly 'phagocytosable' material had been removed (Dresser, 1962; Frei et al, 1965). However, the immune response to some antigens appears to be macrophage independent (see p. 330) and both immunity and paralysis have been induced by exposing isolated lymphoid cells to such antigens in vitro in the absence of phagocytic cells (Diener, Shortman, and Russell, 1970). Moreover, Scott and Waksman (1968) induced specific paralysis by exposing intact rat lymphoid organs to bovine gammaglobulin in vitro although dispersed lymphoid cells were unaffected by the same concentrations. This paradox may be explained by the elegant studies of Mitchison (1964 and 1968) which showed that paralysis can be induced not only after injection of high doses of antigen (high zone paralysis) but also after the injection of sub-immunogenic does (low 
zone paralysis). This raises the possibility that there are different induction pathways for high and low zone paralysis (Nossal, 1969). This possibility has been substantiated by recent studies in vitro. High concentrations of such antigens as polymerized flagellin of Salmonella adelaide and Eschericia coli induced paralysis in isolated mouse lympoid cells (Britton, 1969; Diener and Armstrong, 1969). Paralysis could also be induced with subimmunogenic doses of antigen in vitro but this was dependent on the presence of the corresponding antibody (Feldmann and Diener, 1970; Diener and Feldmann, 1970).

\section{Factors Influencing the Induction of Paraly-} sis. There are a number of factors which affect the facility with which an animal can be paralysed by a particular antigen. Of these the ability of an animal to respond to the antigen seems important. Thus immature animals which have a limited capacity to respond immunologically are particularly susceptible to the induction of paralysis (Smith, 1961; Leskowitz, 1967). In the same way, adult animals can be made more susceptible to the induction of paralysis if they are given immunosuppressive agents. For example, Mitchison (1968) $\mathrm{X}$-irradiated mice and injected them with various antigens. After 10 weeks such mice were specifically less responsive to challenge with the corresponding antigen than $\mathrm{X}$-irradiated or normal controls. Immunosuppressive agents such as cyclophosphamide (Aisenberg and Davies, 1968; Dukor and Dietrich, 1968) and 6 mercaptopurine (Borel and Schwartz, 1964) also render animals more susceptible to paralysis by antigens administered contemporaneously. However, this is probably because these agents eliminate the corresponding antigen-activated cells (see pp. 323 and 324).

The ability of an antigen to elicit an immune response may also be inversely related to the ease with which it induces paralysis. This may provide an explanation of the finding that administration of aggregate-free preparations of heterologous serum proteins induces paralysis whereas aggregated preparations of these antigens result in immunization rather than paralysis (Dresser, 1962; Thorbecke and Benacerraf, 1967; Pinckard, Weir, and McBride, 1967). The physical state of an antigen is probably only one of a number of factors influencing the balance between the induction of immunity and paralysis. Janeway and Sela (1967) observed that the injection of $\mathrm{D}$ amino acids induced paralysis in mice, whereas the corresponding $\mathrm{L}$ polymer evoked an immune response. The $\mathrm{D}$ polymer was shown to be retained about 500 times more efficiently by the cells of the reticulo-endothelial system and metabolized 20 times slower than the $\mathrm{L}$ polymer (Janeway and Humphrey, 1968). This suggests that a dominant factor in the induction of paralysis of this type may be slow catabolism of antigen coupled with high antigen retention.

In this review paralysis is considered to be an antigen-induced defect in the corresponding immunologically competent cells. Such cells appear to be irreversibly inactivated and recovery from paralysis involves the recruitment of new cells. However, recovery from paralysis can be prevented by the continuous presence of the corresponding antigen and consequently permanent antigen-specific suppression of the immune response can be achieved.

\section{Immune Deviation}

It is known that administration of antigen in different forms may result in the expression of individual facets of the immune response. Rats injected with polymerized flagellin produced high titres of IgM antibody whilst IgG antibody with little or no IgM antibody was produced following the injection of soluble flagellin (Ada, Nossal, and Austin, 1965). Similarly, it has been found that the development of delayed hypersensitivity and $\mathrm{IgG}_{2}$ response to ovalbumin in guinea pigs is enhanced by incorporation of the antigen in Freund's complete adjuvant. If the mycobacteria are omitted or if the antigen is absorbed on alum then an $\operatorname{IgG}_{1}$ response occurs and the delayed hypersensitivity response is much weaker (White, Coons, and Connolly, 1955; Wilkinson and White, 1966). In the same way it has been found that some aspects of the immune response can be suppressed while other aspects are unaffected. Thus the $\mathrm{IgG}_{2}$ and delayed hypersensitivity response of adult guinea pigs to antigens in Freund's complete adjuvant is inhibited by prior immunization with the antigen on alum or in incomplete adjuvant whereas the total antibody response is unaffected (Asherson and Stone, 1965; Loewi, Holborow, and Temple, 1966).

The selective loss of delayed hypersensitivity distinguishes this state termed 'immune deviation' from paralysis (Asherson, 1967). All facets of immune response were suppressed in guinea pigs paralysed by administration of aggregate-free antigen (Asherson and Stone, 1965).

The mechanism of immune deviation is not understood. Serum transfer from deviated donors did not affect the induction of delayed hypersensitivity in normal recipients or the detection of delayed hypersensitivity in sensitized recipients. On the other hand peritoneal exudate cells and spleen cells 
from deviated donors had a reduced ability to transfer delayed hypersensitivity to normal recipients although this defect was not evident if large numbers of cells were transferred (Asherson, 1966). This suggests that there is some induced defect in those cells involved in delayed hypersensitivity.

Phenomena akin to immune deviation have been found following the injection of solutions of proteinhapten conjugates in immature guinea pigs (Borel, Fauconnet, and Miescher, 1966 and 1967) and of protein in solution in mice (Crowle and Hu, 1966 and 1970). It seems likely that in these situations there is selective paralysis of the cells involved in delayed hypersensitivity.

\section{Application of Antigen Specific Immunological Suppression}

This final section is devoted to considering how the principles, which have emerged from the basic studies of antigen specific immunological suppression, have been applied.

Auto-immune Diseases. Passive antibody has been shown to interfere with the induction of experimental auto-immune diseases. Paterson and Harwin (1963) obtained pools of serum containing high levels of anti-brain, auto-antibodies from Wistar rats injected with guinea pig brain in Freund's complete adjuvant. Rats injected with this serum were resistant to the development of allergic encephalomyelitis by a contemporaneous sensitizing injection of nervous tissue. The suppressive activity of this serum was associated with a heat labile complement fixing IgM auto-antibody (Paterson, 1964; Paterson, Coia, and Jacobs, 1965). The sera of all normal Wistar rats contain auto-antibodies of this type (Weir et al, 1966; Elson and Weir, 1969) and it is possible that the effect of this serum was to re-inforce an existing state of restricted auto-immunity to tissue antigens. This hypothesis has been elaborated in detail elsewhere (Weir and Elson, 1969). Nevertheless, it seems pertinent to reiterate that a similar interpretation can be made of the finding that the induction of experimental allergic orchitis and thyroiditis can be prevented by injections of the corresponding tissue antigen on alum or incomplete adjuvant, before the sensitizing injection (Brown, Glynn, and Holborow, 1967; Weigle et al, 1967).

Preventive measures of the type described above are not yet applicable to human auto-immune disease. In the first place, they interfere with the induction of an immune response rather than with a response already underway. Secondly, the interplay between the different facets of the immune re- sponse to tissue constituents in the pathogenesis of many human auto-immune diseases is not understood.

Atopy. Attempts to alleviate the effects of im- $\overrightarrow{\vec{P}}$ mediate type hypersensitivity reactions to such $\overline{0}$ antigens as grass pollen by densitizing injections of the pollen in an appropriate form go back to 1911 (Noon, 1911). Whether the effect of desensitizing injections is to deviate the immune response away from the production of IgE antibodies, which have been incriminated as the mediators of immediate type hypersensitivity reactions, has not yet been elucidated.

Prevention of Rhesus Iso-immunization. The first therapeutic application of antigen specific suppression of the immune response exploited the suppressive effect of passive antibody. Clinical trials have shown that the injection of $R h$ negative mothers with anti-Rh antibody after delivery prevents primary $R h$ iso-immunization by fetal ( $R h$ positive) erythrocytes and hence $\mathrm{Rh}$ haemolytic disease of the new born in subsequent pregnancies (Combined Study, 1966; Clarke, 1967; Freda et al, 1967). At the time these trials were initiated little was known about how passive antibody exerted its immunosuppressive effect. Considerable informa tion has accumulated since then (see p. 329) and with hindsight it is possible to see how passive ad? ministered anti- $\mathrm{Rh}$ may prevent $\mathrm{Rh}$ iso-immunization in pregnancy. Mothers who have been protected from immunization by antibody in the first pregnancy may become immunized after a second unprotected pregnancy (J. C. Woodrow, personal communication). It seems likely therefore that anti-Rh antibody does not act 'centrally' and there is a general agreement that it affects the afferent limb of the immune response to the $R h$ antigen (Clarke, 1968; Pollack et al, 1969; Woodrow, 1970). However, the exact means by which anti-Rh antibody prevents access of antigen to the corresponding immunologically competent cells is still in dispute (Clarke, 1970). For example, it is not known whether the administration of anti-Rh antibody to an $\mathrm{Rh}^{-} \mathrm{Kell}^{-}$mother with an $\mathrm{Rh}^{+} \mathrm{Kell}^{+}$ baby prevents immunization to the $\mathrm{Rh}$ antigen alone or to both the $\mathrm{Rh}$ and Kell antigen.

Transplantation of Tissues and Organs. Attempts have been made to exploit the fact that animals can be paralysed by the action of immunosuppressive agents on antigen activated immunologically competent cells. This principle has been applied to human bone marrow transplantation. The prospective recipient was given donor antigens 
in the form of peripheral blood leucocytes followed by a four day course of cyclophosphamide to eliminate any proliferating immunologically competent cells. The recipient was given $3 \times 10^{9}$ bone marrow cells intravenously 3 days later. The success of this treatment was shown by the chimaeric state of the patient who did not develop graft versus host disease (Bach et al, 1968).

The knowledge that passive administration of antibody can suppress the immune response to the corresponding antigen has led a number of workers to examine the effect of anti-allograft serum on allograft survival. For example, French and Batchelor (1969) transplanted (SA $\times$ August) $F_{1}$ hybrid kidneys into SA rats. The mean survival time of the kidneys was 8.5 days. This contrasted with the prolonged (over 4 months) survival of kidneys in rats treated with anti-August allo-antibody at the time of transplantation. These kidneys survived despite the production by the recipient of antibodies which were cytotoxic in vitro to August lymphoid tissue. This suggests that graft survival was not the result of passive allo-antibody preventing access of donor antigens to the recipient's antigensensitive cells. Rowley et al (1969) too, noted that the survival time of rat kidney allografts was extended by treatment of recipients with anti-donor serum at the time of transplantation. A similar extension of graft survival was obtained by giving an intravenous injection of $10^{8}$ donor lymphoid cells one day before transplantation. Combining the two treatments extended graft survival almost indefinitely. There is evidence which suggests that this may not be due to selective paralysis of the corresponding immunologically competent cells. Isolated spleen cells from rats with surviving allografts were competent to initiate graft versus host disease in normal rats of the donor strain (Okner, Guttman, and Lindquist, 1970). Possibly the common denominator determining graft survival in these experiments may be the production by the recipient of an antigraft antibody which in some way prevents graft destruction.

The above studies were carried out with minimal histocompatibility differences between the donor and recipient, and although anti-graft antibodies may prolong graft survival in this situation they can in other conditions produce graft rejection. Antigraft antibodies have been implicated in both the hyperacute and late rejection of kidney allografts in humans (Terasaki, Marchiora, and Starzl, 1965; Williams et al, 1968; Najarian and Foker, 1969). Thus, the effects of antibody on grafts are complex and not clearly understood. Nevertheless, it appears that there is a need for the evaluation of these means of inducing antigen-specific suppression of homograft immunity to clinical organ transplantation.

We thank Professor C. A. Clarke and Mrs Joanna Elson for helpful discussion and criticism.

\section{REFERENCES}

Ada, G. L., Nossal, G. J. V., and Austin, C. M. (1965). Studies on the nature immunogenicity employing soluble and particulate bacterial proteins. In Molecular and Cellular Basis of Antibody Formation, ed. J. Sterzl, pp. 31-42. Czechoslovak Academy of Sciences, Prague.

Adler, F. L., Fishman, M., and Dray, S. (1966). Antibody formation initiated in vitro. III. Antibody formation and allotypic specificity directed by ribonucleic acid from peritoneal exudate cells. Fournal of Immunology, 97, 554-558.

Aisenberg, A. C. and Davis, C. (1968). The thymus and recovery from cyclophosphamide-induced tolerance to sheep erythrocytes. Fournal of Experimental Medicine, 128, 35-46.

Ambrose, C. T. (1964). The requirement for hydrocortisone in antibody-forming tissues cultivated in serum-free medium. Fournal of Experimental Medicine, 119, 1027-1049.

Argyris, B. F. (1963). Adoptive tolerance; transfer of the tolerant state. Fournal of Immunology, 90, 29-34.

Asherson, G. L. (1966). Selective and specific inhibition of 24 hour skin reactions in the guinea-pig. II. The mechanism of immune deviation. Immunology, 10, 179-186.

Asherson, G. L. (1967). Autoimmune disease I. British Medical fournal, 3, 417-420.

Asherson, G. L. and Stone, S. H. (1965). Selective and specific inhibition of 24 hour skin reactions in the guinea-pig. I. Immune deviation: Description of the phenomenon and the effect of splenectomy. Immunology, 9, 205-217.

Askonas, B. A and Rhodes, J. M. (1965). Immunogenicity of antigen-containing ribonucleic acid preparations from macrophages. Nature, 205, 470-474.

Axelrad, M. A. (1968). Suppression of delayed hypersensitivity by antigen and antibody. Is a common precursor cell responsible for both delayed hypersensitivity and antibody formation. Immunology, 15, 159-171.

Bach, F. H., Albertini, R. J., Anderson, J. L., Joo, P., and Bortin, M. M. (1968). Bone-marrow transplanation in a patient with the Wiskott-Aldrich syndrome. Lancet, 2, 1364-1366.

Berenbaum, M. C. (1962). The effect of cytotoxic agents on the production of antibody to TAB vaccine in the mouse. Biochemical Pharmacology, 11, 29-44.

Berenbaum, M. C. and Brown, I. N. (1965). The effect of delayed administration of folinic acid on immunological inhibition by methotrexate. Immunology, 8, 251-259.

Berken, A. and Benacerraf, B. (1966). Properties of antibodies cytophilic for macrophages. Fournal of Experimental Medicine, 123, 119-144.

Bertino, J. R. (1963). The mechanism of action of the folate antagonists in man. Cancer Research, 23, 1286-1306.

Besredka, A. (1900). La leucotoxine et son action sur le systeme leucocytaire. Annales de l'Institut Pasteur, 14, 390-402.

Biberfeld, P., Holm, G., and Perlmann, P. (1969). Inhibition of lymphocyte peripolesis and cytotoxic action in vitro by antilymphocyte serum (ALS). Experimental Cell Research, 54, 136139.

Billingham, R. E. and Brent, L. (1959). Quantitative studies on tissue transplantation immunity. IV. Induction of tolerance in new born mice and studies on the phenomenon of runt disease. Philosophical Transactions of the Royal Society of London, Series B. Biological Sciences, 242, 439.

Billingham, R. E., Brent, L., and Medawar, P. B. (1953). Actively acquired tolerance of foreign cells. Nature, 172, 603-606.

Billingham, R. E., Brent, L., and Medawar, P. B. (1956). Quantitative studies on tissue transplantation immunity. III. Actively acquired tolerance. Philosophical Transactions of the Royal Society of London, Series B. Biological Sciences, 239, 357-412.

Blinkoff, R. C. (1966). $\quad \gamma M$ and $\gamma \mathrm{G}$ antibodies in mice: dissociation of the normal immunoglobulin sequence. Fournal of Immunology, 97, 736-746. 
Borel, Y., Fauconnet, M., and Miescher, P. A. (1965). Effect of 6-mercaptopurine (6MP) on different classes of antibody. Fournal of Experimental Medicine, 122, 263-275.

Borel, Y., Fauconnet, M., and Miescher, P. A. (1966). Selective suppression of delayed hypersensitivity by the induction of immunologic tolerance. Fournal of Experimental Medicine, 123, 585-598.

Borel, Y., Fauconnet, M., and Miescher, P. (1967). Dissociation of immune responses by the induction of partial unresponsiveness. fournal of Immunology, 98, 881-887.

Borel, Y. and Schwartz, R. S. (1964). Inhibition of immediate and delayed hypersensitivity in the rabbit by 6-mercaptopurine. fournal of Immunology, 92, 754-761.

Brent, L., Courtenay, T., and Gowland, G. (1967). Immunological reactivity of lymphoid cells after treatment with anti-lymphocytic serum. Nature, 215, 1461-1464.

Britton, S. (1969). Regulation of antibody synthesis against Escherichia coli endotoxin. IV. Induction of paralysis in vitro by treating normal lymphoid cells with antigen. Fournal of Experimental Medicine, 129, 469-482.

Brody, N. I., Walker, J. G., and Siskind, G. W. (1967). Studies on the control of antibody synthesis. Interaction of antigenic competition and suppression of antibody formation by passive antibody on the immune response. Fournal of Experimental Medicine, 126, 81-91.

Brooke, M. S. and Karnovsky, M. J. (1961). Immunological paralysis and adoptive immunity. Fournal of Immunology, 87, 205-208.

Brown, P. C., Glynn, L. E., and Holborow, E. J. (1967). The dual necessity for delayed hypersensitivity and circulating antibody in the pathogenesis of experimental allergic orchitis in guinea-pigs. Immunolgy, 13, 307-314.

Burnet, F. M. (1941). The Production of Antibodies, 1st ed. Macmillan, Melbourne.

Caron, G. A. (1967). The effect of antimetabolites and corticosteroids on lymphocyte transformation in vitro. Proceedings of the Leucocyte Culture Conference, ed. W. O. Reike, p. 287. Appleton Croft, New York.

Cerottini, J. C., McConahey, P. J., and Dixon, F. J. (1969). The immunosuppressive effect of passively administered antibody IgG fragments. Fournal of Immunology, 102, 1008-1015.

Chanmougan, D. and Schwartz, R. S. (1966). Enhancement of antibody synthesis by 6-mercaptopurine. Fournal of Experimental Medicine, 124, 363-378.

Chew, W. B. and Lawrence, J. S. (1937). Antilymphocyte serum. fournal of Immunology, 33, 271-278.

Clarke, C. A. (1967). Prevention of Rh-haemolytic disease. British Medical fournal, 4, 7-12.

Clarke, C. A. (1968). Prevention of Rhesus iso-immunisation. Seminars in Hematology, 6, 201-224.

Clarke, C. A. (1970). Prevention of rhesus isoimmunization. Clinical Genetics, 1, 183-215.

Claman, H. N. and Talmage, D. W. (1963). Thymectomy: prolongation of immunological tolerance in the adult mouse. Science, 141, 1193-1194.

Combined Study from centres in England and Baltimore: Prevention of Rh-haemolytic disease: Results of the clinical trial (1966). British Medical fournal, 2, 907-914.

Cooperband, S. R., Davis, R. C., Schmid, K., and Mannick, J. A. (1967). Competitive blockade of lymphocyte stimulation by serum immuno-regulatory alpha globulin (IRA). Transplantation Proceedings, 1, 516-523.

Corley, C. C., Lessner, H. E., and Larsen, W. E. (1966). Azathioprine therapy of 'auto-immune' diseases. American fournal of Medicine, 41, 404-412.

Cornwell, S. (1953). Studies of reticuloendothelial function with colloidal gold. (Abstr.) Anatomical Record, 115, 295.

Crowle, A. J. and Hu, C. C. (1966). Split tolerance affecting delayed hypersensitivity and induced in mice by pre-immunisation with protein antigens in solution. Clinical and Experimental Immunology, 1, 323-335.

Crowle, A. J., and Hu, C. C. (1970). Studies on the induction and time course of repression of delayed hypersensitivity in the mouse by low and high doses of antigen. Clinical and Experimental Immunology, 6, 363-374.

Cruickshank, A. H. (1941). Anti-lymphocytic serum. British fournal of Experimental Pathology, 22, 126-136.

Denman, A. M. and Frenkel, E. P. (1968). Mode of action of antilymphocyte globulin. II. Changes in the lymphoid cell population in rats treated with anti-lymphocyte globulin. Immunology, 14, 115-126.

Diener, E. and Armstrong, W. D. (1969). Immunological tolerance in vitro: kinetic studies at the cellular level. Fournal of Experimental Medicine, 129, 591-603.

Diener, E. R. and Feldmann, M. (1970). Antibody-mediated suppression of the immune response in vitro. II. A new approach to the phenomenon of immunological tolerance. Fournal of Experimental Medicine, 132, 31-43.

Diener, E. G., Shortman, K., and Russell, P. (1970). Induction of immunity and tolerance in vitro in the absence of phagocytic cells. Nature, 225, 731-732.

Diengdoh, J. V. and Turk, J. L. (1966). A cytochemical study of the cellular changes in lymph nodes during the development of contact sensitivity and its inhibition by methothrexate. International Archives of Allergy and Applied Immunology, 29, 224-239.

Dietrich, F. M. (1966). Inhibition of antibody formation to sheep erythrocytes by various tumour-inhibiting chemicals. International Archives of Allergy and Applied Immunology, 29, 313-328.

Dietrich, F. M. and Weigle, W. O. (1964). Immunologic unresponsiveness to heterologous serum proteins induced in adult mice and transfer of the unresponsive state. Fournal of Immunology, 92, 167-172.

Dixon, F. J., Jacot-Guillarmod, H., and McConahey, P. J. (1967). The effect of passively administered antibody on antibody synthesis. Fournal of Experimental Medicine, 125, 1119-1135.

Dongern, V. (1906). Contributions to the study of immunity. In Collected Studies on Immunity, ed. P. Ehrlich, chapter IV, p. 36. John Wiley, New York.

Dresser, D. W. (1962). Specific inhibition of antibody production. II. Paralysis induced in adult mice by small quantities of protein antigen. Immunology, 5, 378-388.

Dukor, P. and Dietrich, F. M. (1968). Characteristic features of immunosuppression by steroids and cytotoxic drugs. International Archives of Allergy and Applied Immunology, 34, 32-48.

Elion, G. B., Hitchings, G. H., and Vanderwerff, H. (1951). Antagonists of nucleic acid derivatives. VI. Purines. Fournal of Biological Chemistry, 192, 505-518.

Elson, C. J. and Weir, D. M. (1969). Development of anti-tissue antibodies in rats. Clinical and Experimental Immunology, 4 241-246.

Feldmann, M. and Diener, E. (1970). Antibody-mediated suppression of the immune response in vitro. I. Evidence for a central effect. Fournal of Experimental Medicine, 131, 247-274.

Felton, L. D. and Bailey, G. H. (1926). Biologic significance of the soluble specific substances of pneumococci. Fournal of Infectious Diseases, 38, 131-144.

Felton, L. D. and Ottinger, B. (1942). Pneumococcus polysaccharide as a paralysing agent on the mechanism of immunity in white mice. Fournal of Bacteriology, 43, 94-95.

Fishman, M., Rood, J. J. van, and Adler, F. L. (1965). The initiation of antibody formation by ribonucleic acid from specifically stimulated macrophages. In Molecular and Cellular Basis of Antibody Formation, ed. J. Sterzl, pp. 491-501. Czechoslovak Academy of Sciences, Prague.

Flexner, S. and Noguchi, H. (1903). Snake venom in relation to haemolysis, bacteriolysis and toxicity. Fournal of Experimental Medicine, 6, 277-301.

Franksson, C. (1964). Survival of homografts of skin in rats depleted of lymphocytes by chronic drainage from the thoracic duct. Lancet, 1, 1331-1332.

Freda, V. J., Gorman, J. G., Pollack, W., Robertson, J. G., Jennings, E. R., and Sullivan, J. F. (1967). Prevention of Rh isoimmunisation. Progress report of the clinical trial in mothers. Fournal of the American Medical Association, 199, 390-394.

Frei, P. C., Benacerraf, B., and Thorbecke, G. J. (1965). Phagocytosis of the antigen, a crucial step in the induction of the primary response. Proceedings of the National Academy of Sciences of the United States of America, 53, 20-23.

French, M. E. and Batchelor, J. R. (1969). Immunological enhancement of rat kidney grafts. Lancet, 2, 1103-1106.

Friedman, H. (1962). Transfer of antibody formation by spleen cells from immunologically unresponsive mice. Fournal of Immunology, 89, 257-263.

Friedman, R. M. and Buckler, C. E. (1963). Mechanism of methotrexate action on tuberculin hypersensitivity in guinea-pigs Federation Proceedings, 22, 501. 
Friedman, R. M., Buckler, C. E., and Baron, S. (1961). The effect of aminomethylpteroylglutamic acid on the development of skin hypersensitivity and on antibody formation in guinea-pigs. fournal of Experimental Medicine, 114, 173-183.

Frisch, A. W. and Davies, G. H. (1962). Inhibition of hemagglutinin formation by thioguanine: Dose-time relationships. Proceedings of the Society for Experimental Biology and Medicine, New York, 110, 444-447.

Frisch, A. W. and Davies, G. H. (1965). Inhibition of haemagglutinin synthesis by cytoxan. Cancer Research, 25, 745-751.

Gabrielsen, A. E. and Good, R. A. (1967). Chemical suppression of adaptive immunity. Advances in Immunology, 6, 91-229.

Gell, P. G. H. and Hinde, I. T. (1951). The histology of the tuberculin reaction and its modification by cortisone. British fournal of Experimental Pathology, 32, 516-529.

Gell, P. G. H. and Hinde, I. T. (1953). The effect of cortisone on macrophage activity in mice. British fournal of Experimental Pathology, 34, 273-275.

Gleason, R. E. and Murray, J. E. (1967). Report from Kidney Transplant Registry: Analysis of variables in the function of human kidney transplants. II. Immunosuppressive regimens. Transplantation, 5, 360-373.

Gowans, J. L., McGregor, D. D., Cowen, D. M., and Ford, C. E. (1962). Initiation of immune responses by small lymphocytes. Nature, 196, 651-655.

Hamburger, J., Vaysse, J., Crosnier, J., Auvert, J., Lalanne, C. M., and Hopper, J. (1962). Renal homotransplantation in man after radiation of the recipient. American fournal of Medicine, 32, 854-871.

Hampton, A. (1963). Reactions of ribonucleotide derivatives of purine analogues at the catalytic site of inosine 5-phosphate dehydrogenase. Fournal of Biological Chemistry, 238, 3068-3074.

Harris, G. and Cramp, W. A. (1968). Further studies of antigen stimulation of deoxyribonucleic acid synthesis in rabbit spleen cell cultures. I. The effects of centrifuged proteins. Immunology, $14,409-414$

Hektoen, L. and Corper, H. J. (1921). The effect of mustard gas (dichlorethylsulphid) on antibody formation. fournal of Infectious Diseases, 28, 279-285.

Henney, C. S. and Ishizaka, K. (1968). Studies on the immunogenicity of antigen-antibody precipitates. I. The suppressive effect of anti- $\mathrm{L}$ and anti- $\mathrm{H}$ chain antibodies on the immunogenicity of human $\gamma \mathrm{G}$ globulin. Fournal of Immunology, 101, 896904.

Henry, C. and Jerne, N. K. (1968). Competition of $19 \mathrm{~S}$ and $7 \mathrm{~S}$ antigen receptors in the regulation of the primary immune response. Fournal of Experimental Medicine, 128, 133-152.

Hersh, E. M., Carbone, P. P., Wong, V. G., and Freireich, E. J. (1965). Inhibition of the primary immune response in man by antimetabolites. Cancer Research, 25, 997-1001.

Hirschhorn, K., Bach, F., Kolodny, R. L., Firschein, I. L., and Hashem, N. (1963). Immune response and mitosis of human peripheral blood lymphocytes in vitro. Science, 142, 1185-1187.

Holt, L. J., Ling, N. R., and Stanworth, D. R. (1966). The effect of heterologous antisera and rheumatoid factor on the synthesis of DNA and protein by human peripheral lymphocytes. Immunochemistry, 3, 359-372.

Hume, D. M., Jackson, B. T., Zukosi, C. F., Lee, H. M., Kaufman, H. M., and Egdahl, R. H. (1960). The homotransplantation of kidneys and of foetal liver and spleen after total body irradiation. Annals of Surgery, 152, 354-373.

Hume, D. M., Magee, J. H., Prout, G. R., Kauffman, H. M., Cleveland, R. H., Bower, J. D. and Lee, H. M. (1964). Studies of renal homostransplantation in man. Annals of the New York Academy of Sciences, 120, 578-606.

Humphrey, J. H. (1964). Immunological unresponsiveness to protein antigens in rabbits. I. The duration of unresponsiveness following a single injection at birth. Immunology, 7, 449-461.

Hurd, E. and Ziff, M. (1968). Studies on the anti-inflammatory action of 6-mercaptopurine. Fournal of Experimental Medicine, 128, 785-800.

Inderbitzin, T. (1956). The relationship of lymphocytes, delayed cutaneous allergic reactions and histamine. International Archives of Allergy and Applied Immunology, 8, 150-159.

Ivanyi, J. (1970). Cytophilic antibodies in passive antibody induced immune suppression or enhancement. Nature, 226, 550 551.

6-J.M.G.
James, K. (1967a). Antilymphocytic antibody. A review. Clinical and Experimental Immunology, 2, 615-631.

James, K. (1967b). Some factors influencing the ability of antilymphocytic antibody to suppress humoral antibody formation Clinical and Experimental Immunology, 2, 685-690.

James, K. (1969). The preparation and properties of anti-lymphocytic sera. Progress in Surgery, 7, 140-216.

James, K. and Jubb, V. S. (1967). Effect of anti-rat lymphocyte antibody on humoral antibody formation. Nature, 215, 367-371.

Janeway, C. A. and Humphrey, J. H. (1968). Synthetic antigens composed exclusively of $\mathrm{L}$ - or $\mathrm{D}$-amino acids. II. Effect of optical configuration on the metabolism and fate of synthetic polypeptide antigens in mice. Immunology, 14, 225-234.

Janeway, C. A. and Sela, M. (1967). Synthetic antigens composed exclusively of L- or D-amino acids. I. Effect of optical configuration on the immunogenicity of synthetic polypeptides in mice. Immunology, 13, 29-38.

Kamrin, B. B. (1959). Successful skin homografts in mature nonlittermate rats treated with fractions containing $\alpha$ globulins. Proceedings of the Society for Experimental Biology and Medicine, $100,58-61$.

Kamrin, B. B. (1969). Role of alpha globulins in immunosuppression: Reactive site occlusion hypothesis. Transplantation Proceedings, 1, 506-510.

Kass, E. H., Kendrick, M. I., and Finland, M. (1953). Effect of certain corticosteroids and of growth hormone of nucleoproteins of lymph nodes. Annals of the New York Academy of Sciences, 56, 737-741.

Lambert, P. H. and Dixon, F. J. (1968). Pathogenesis of the glomerulonephritis of NZB/W mice. Fournal of Experimental Medicine, 127, 507-522.

Lance, E. M. (1968). Erasure of immological memory with ALS. Nature, 217, 557-558.

Lance, E. M. (1970). The selective action of antilymphocyte serum on recirculating lymphocytes. Clinical and Experimental Immunology, 6, 789-802.

Lance, E. M. and Batchelor, J. R. (1968). Selective suppression of cellular immunity by ALS. Transplantation, 6, 490-491.

Lance, E. M., Ford, P. J., and Ruszkiewicz, M. (1968). The use of subcellular fractions to raise antilymphocytic serum. Immuno$\log y, 15,571-580$.

Lance, E. M., Levey, R. H., and Medawar, P. B. (1969). Tolerance of rat skin grafts in adult mice. Proceedings of the National Academy of Sciences of the United States of America, 64, 1356-1361.

Lance, E. M. and Medawar, P. B. (1968). Survival of skin heterografts under treatment with anti-lymphocytic serum. Lancet, 1, 1174-1176.

Lemmel, E. M. and Good, R. A. (1969). Immunosuppressive action of Mitomycin $\mathrm{C}$ on lymphoid cells. International Archives of Allergy and Applied Immunology, 36, 554-565.

Leskowitz, S. (1967). Tolerance. Annual Review of Microbiology, 21, 157-180.

Levey, R. H. and Medawar, P. B. (1966). Nature and mode of action of antilymphocytic antiserum. Proceedings of the National Academy of Sciences of the United States of America, 56, 1130-1137.

Levey, R. H. and Medawar, P. B. (1967). Further experiments on the action of antilymphocytic antiserum. Proceedings of the National Academy of Sciences of the United States of America, 58, 470-477.

Loewi, G., Holborow, E. J., and Temple, A. (1966). Inhibition of delayed hypersensitivity by pre-immunization without complete adjuvant. Immunology, 10, 339-347.

Lurie, M. B. (1960). The reticuloendothelial system, cortisone and thyroid function: their relation to native resistance to infection. Annals of the New York Academy of Sciences, 88, 83-98.

Mannick, J. A. and Egdahl, R. H. (1968). Endocrinologic Agents in Human Transplantation, ed. F. T. Rapaport and J. Dausset, chapter 29, p. 472. Grune and Stratton, New York.

Mannick, J. A. and Schmid, K. (1967). Prolongation of allograft survival by an alpha globulin isolated from normal blood. Transplantation, 5, 1231-1245.

Mason, J. H., Robinson, M., and Christensen, P. A. (1955). The Active immunisation of guinea-pigs passively immunised with homologous anti-toxic serum. fournal of Hygiene, 53, 172-179.

McCullagh, P. J. and Gowans, J. L. (1967). Quoted by J. W. Uhr and G. Möller in Advances in Immunology, 8, 116. 
McGregor, D. D. and Gowans, J. L. (1964). Survival of homografts of skin in rats depleted or lymphocytes by chronic drainage from the thoracic duct. Lancet, 1, 629-632.

Meeker, W. P., Condie, R. M., Good, R. A., and Varco, R. L. (1960). Alteration of the homograft response by antimetabolites. Annals of the New York Academy of Sciences, 87, 203-213.

Merrill, J. P. (1962). Treatment of renal disease with combined steroid therapy and antimetabolites. Blood, 20, 119.

Merrill, J. P. (1968). Medical management of the transplant patient. In Human Transplantation, ed. F. J. Rapaport and J. Dausset, pp. 66-99. Grune and Stratton, New York.

Merrill, J. P., Murray, J. E., Harrison, J. H., Friedman, E. A., Dealy, J. B., Jr., and Dammin, G. J. (1960). Successful homotransplantation of the kidney between non-identical twins. New England Fournal of Medicine, 262, 1251-1260.

Metchnikoff, E. (1899). Études sur la resorption des cellules. Annales de l'Institut Pasteur, 13, 737-769.

Miller, J. F. A. P., Doak, S. M. A., and Cross, A. M. (1963). Role of the thymus in recovery of the immune mechanism in the irradiated adult mouse. Proceedings of the Society for Experimental Biology and Medicine, 112, 785-792.

Miller, J. F. A. P. and Mitchell, G. F. (1968). Cell to cell interaction in the immune response. I. Haemolysin-forming cells in neonatally thymectomised mice reconstituted with thymus or thoracic duct lymphocytes. Fournal of Experimental Medicine, 128, 801-820.

Miller, J. F. A. P. and Osoba, D. (1967). Current concepts of the immunological function of the thymus. Physiological Reviews, 47, 437-520.

Mitchell, G. F. and Miller, J. F. A. P. (1968). Immunological activity of thymus and thoracic-duct lymphocytes. Proceedings of the National Academy of Sciences of the United States of America, 59, 296-303.

Mitchison, N. A. (1964). Induction of immunological paralysis in two zones of dosage. Proceedings of the Royal Society, Series B, Biological Sciences, 161, 275-292.

Mitchison, N. A. (1965). Recovery from immunological paralysis in relation to age and residual antigen. Immunology, 9, 129-138.

Mitchison, N. A. (1968). The dosage requirements for immunological paralysis by soluble proteins. Immunology, 15, 509-530.

Möller, E. (1965). Antagonistic effects of humoral isoantibodies on the in vitro cytotoxicity of immune lymphoid cells. Fournal of Experimental Medicine, 122, 11-23.

Möller, G. (1964). Antibody induced depression of the immune response. A study of the mechanism in various immunological systems. Transplantation Bulletin, 2, 405-415.

Monaco, A. P., Wood, M. L., Gray, J. G., and Russell, P. S. (1966). Studies on heterologous anti-lymphocyte serum in mice. Fournal of Immunology, 96, 229-238.

Monaco, A. P., Wood, M. L., and Russell, P. S. (1967). Some effects of purified heterologous anti-human lymphocyte serum in man. Transplantation, 5, 1106-1114.

Mowbray, J. F. (1963). Ability of large doses of an alpha 2 plasmaprotein fraction to inhibit antibody production. Immunology, 6 217-225.

Mowbray, J. F. and Hargrave, D. C. (1966). Further studies on the preparation of the immunosuppressive alpha $_{2}$ protein fraction from serum and its assay in mice. Immunology, 11, 413-420.

Mowbray, J. F. and Scholand, J. (1966). Inhibition of antibody production by tibonucleases. Immunology, 11, 421-426.

Müller-Eberhard, H. J. (1967). Chemistry and reaction mechanisms of complement. Advances in Immunology, 8, 2-72.

Najarian, J. S. and Foker, J. E. (1969). Mechanisms of kidney allograft rejection. Transplantation Proceedings, 1, 184-193.

Nagaya, H. and Sieker, H. A. (1967). Feedback mechanisms of thymic lymphocyte production. Proceedings of the Society for Experimental Biology and Medicine, 126, 131-135.

Neiders, M. E., Rowley, D. A., and Fitch, F. W. (1962). The sustained suppression of hemolysin response in passively immunized rats. Fournal of Immunology, 88, 718-724.

Nettesheim, P., Makinodan, T., and Williams, M. L. (1967). Regenerative potential of immunocompetent cells. I. Lack of recovery of secondary antibody-forming potential after $\mathrm{X}$-irradiation. fournal of Immunology, 99, 150-157.

Noon, L. (1911). Prophylactic innoculation against hay fever. Lancet, 1, 1572-1573.

Nossal, G. J. V. (1957). The immunological response of foetal mice to influenza virus. Australian fournal of Experimental Biology and Medical Science, 35, 549-557.
Nossal, G. J. V. (1969). Antigen Dosage in Relation to Responsiveness and Nonresponsiveness in Immunological Tolerance, ed. M. Landy and W. Braun. Academic Press, New York.

Ockner, S. A., Guttmann, R. D., and Lindquist, R. R. (1970). Renal transplanation in the inbred rat. XIV. Mechanism of the modified rejection produced by bone marrow cell pretreatment. Transplantation, 9, 39-48.

Olitzki, L. (1935). The antigenic properties of bacteria combined with antibodies. Fournal of Immunology, 29, 453-465.

Otte, H. and Grosjean, O. (1964). Transplantation allogénique de rein et conditionnement de l'hôte. Comptes Rendus des Séances de la Société de Biologie et de ses Filiales, 158, 909-911.

Page, A. R., Good, R. A., and Pollara, B. (1969). Long-term reresults of therapy in patients with chronic liver disease associated with hypergammaglobulinaemia. American fournal of Medicine, 47, 765-774.

Palm, G. and Liss, E. (1966). Sensitivity of different phases in the cell cycle of ascites tumour cells under the influence of cyclophosphamide. Antimicrobial Agents and Chemotherapy, pp. 493502.

Parker, C. W. and Vavra, J. D. (1969). Immunosuppression. Progress in Hematology, 6, 1-120.

Paterson, P. Y. (1964). Experimental allergic encephalomyelitis and autoimmune disease. Advances in Immunology, 5, 131-208.

Paterson, P. Y., Coia, E. M., and Jacobs, A. F. (1965). Complement- $\omega$ fixing anti-brain antibodies and allergic ancephalomyelitis. I. Characterization of the antibodies. Annals of the New York 응 Academy of Sciences, 122, 256-265.

Paterson, P. Y. and Harwin, S. M. (1963). Suppression of allergic encephalomyelitis in rats by means of antibrain serum. Fournal of Experimental Medicine, 117, 755-774.

Pearlman, D. S. (1967). The influence of antibodies on immunologic responses. I. The effect on the response to particulate antigen in the rabbit. Fournal of Experimental Medicine, 126, 127148.

Piel, C., Koulischer, N., Hock, M., Goodman, J., and Rames, L. (1969). Treatment of nephrosis with azathioprine. Paediatrif Research, 3, 363.

Pierce, C. W. (1969a). Immune responses in vitro. I. Cellular re quirements for the immune response by nonprimed and prime spleen cells in vitro. Fournal of Experimental Medicine, 130, 34fo 364.

Pierce, C. W. (1969b). Immune responses in vitro. II. Suppression of the immune responses in vitro by specific antibody. fournal of Experimental Medicine, 130, 365-380.

Pinckard, R. N., Weir, D. M., and McBride, W. H. (1967). Factors influencing the immune response. I. Effects of the physical state of the antigen and of lymphoreticular cell proliferation on the response to intravenous injection of bovine serum albumin in rabbits. Clinical and Experimental Immunology, 2, 331-341.

Pollack, W., Gorman, J. G. and Freda, V. J. (1969). Prevention of Rh haemolytic disease. Progress in Hematology, 6, 121-147.

Pollack, W., Gorman, J. G., Hager, H. J., Freda, V. J., and Tripodi, D. (1968). Antibody-mediated immune suppression to the $\mathrm{Rh}$ factor: animal models suggesting mechanism of action. Transfusion, 8, 134-145.

Prichard, R. W. and Hayes, D. M. (1961). The effects of aminopterin on guinea-pig tuberculosis. American fournal of Pathology', 38, 325-333.

Pullar, D. M., James, K., and Naysmith, J. D. (1968). The effect of an $\alpha$ globulin preparation and of polyribonuclease complexes on humoral antibody formation. Clinical and Experimental Immunology, 3, 457-461.

Rosenau, W. and Moon, H. D. (1962). The inhibitory effect of hydrocortisone on lysis of homologous cells by lymphocytes in vitro. Fournal of Immunology, 89, 422-426.

Rowley, D. A. and Fitch, F. W. (1964). Homeostasis of antibody formation in the adult rat. Fournal of Experimental Medicine, 120, 987-1005.

Rowley, D. A. and Fitch, F. W. (1967). Clonal Selection and Inhiti tion of the Primary Antibody Response by Antibody in Regulation of the Antibody Response, ed. B. Cinader, p. 27, C. C. Thomas, Springfield.

Rowley, D. A., Fitch, F. W., Saiton, T., and Stuart, F. P. (1969). Specific suppression of cell mediated immune response. Transplantation Proceedings, 1, 580-582.

Russell, P. S. (1968). Antilymphocyte serum as in immunosuppressive agent. Annals of Internal Medicine, 68, 483-486. (1)

\section{.}


Russell, P. S. and Monaco, A. P. (1967). Heterologous antilymphocyte sera and some of their effects. Transplantation, 5, 10861099.

Sachs, H. (1906). Immunising experiments with erythrocytes laden with immune body. In Collected Studies on Immunity, ed. P. Ehrlich, chapter XIII, p. 158 . John Wiles, New York.

Salmonsen, C. J. and Madson, T. (1898). Sur la reproduction de la substance antitoxique après de fortes saignées. Annales de l'Institut Pasteur, 12, 763-773.

Santos, G. W. (1967). Immunosuppressive drugs I. Federation Proceedings, 26, 907-913.

Santos, G. W. and Owens, A. H. (1964). A comparison of the effects of selected cytotoxic agents on the primary agglutinin response in rats injected with sheep erythrocytes. Bulletin of the fohns Hopkins Hospital, 114, 384-401.

Santos, G. W. and Owens, A. H. (1965). A comparison of the effects of selected cytoxic agents on allogeneic skin graft survival in rats. Bulletin of the fohns Hopkins Hospital, 116, 327-340.

Santos, G. W. and Owens, A. H. (1966). $19 \mathrm{~S}$ and $7 \mathrm{~S}$ antibody production in the cyclophosphamide-or methotrexate-treated rat. Nature, 209, 622-624.

Santos, G. W., Owens, A. H., and Sensenbrenner, L. L. (1964), Effects of selected cytoxic agents on antibody production in man; a preliminary report. Annals of the Nerv York Academy of Sciences, 114, 404-423.

Sarles, H. E., Remmers, A. R., Fish, J. C., Canales, C. O., Thomas, F. D., Tyson, K. R. T., Beathard, G. A., and Ritzmann, S. E. (1970). Depletion of lymphocytes for the protection of renal allografts. Archives of Internal Medicine, 125, 443-450.

Schrek, R. and Batra, K. V. (1966). Thymic, splenic and appendiceal lymphocytes. Lancet, 2, 444-445.

Schwartz, R. S. (1968). Immunosuppressive drug therapy. In Human Transplantation, ed. F. T. Rapaport and J. Dausset, p. 440. Grune and Stratton, New York.

Schwartz, R. S., Eisner, A., and Dameshek, W. (1959). The effect of 6-MP on primary and secondary immune responses. fournal of Clinical Investigation, 38, 1394-1403.

Schwartz, M. R., Tyler, R. W., and Everett, N. B. (1968). Mixed lymphocyte reaction: an in vitro test for antilymphocytic serum activity. Science, 160, 1014-1017.

Scott, D. W. and Waksman, B. H. (1968). Tolerance in vitro: suppression of immune responsiveness to bovine $\gamma$-globulin after injection of antigen into intact lymphoid organs. Fournal of Immunology, 100, 912-914.

Sekiguchi, M. and Takagi, Y. (1960). Effect of mitomycin C on the synthesis of bacterial and viral deoxyribonucleic acid. Acta Biochemica et Biophysica Academiae Scientiarum Hungaricae, 41, 434-443.

Sell, S. (1969). Antilymphocytic antibody: Effects in experimental animals and problems in human use. Annals of Internal Medicine, 71, 177-196.

Shortman, K., Diener, E., Russell, P., and Armstrong, W. D. (1970). The role of nonlymphoid accessory cells in the immune response to different antigens. Fournal of Experimental Medicine, 131, 461-482.

Sinclair, N. R. StC. (1969). Regulation of the immune response. I. Reduction in ability of specific antibody to inhibit long-lasting IgG immunological priming after removal of the Fc fragment. fournal of Experimental Medicine, 129, 1183-1202.

Smiley, J. D., Heard, J. G., and Ziff, M. (1964). Effect of actinomycin $O$ on RNA synthesis and antibody formation in the anamnestic response in vitro. Fournal of Experimental Medicine, 119, 881-894.

Smith, R. T. (1961). Immunological tolerance of non-living antigens. Advances in Immunology, 1, 67-129.

Smith, T. (1909). Active immunity produced by so-called balanced or neutral mixtures of diphtheria toxin and anti-toxin. fournal of Experimental Medicine, 11, 241-256.

Sorkin, E. (ed.) (1969). The Immune Response and its Suppression. Krager, Basel, Switzerland, and New York.

Spiegelberg, H. L. and Weigle, W. O. (1964). Effect of an alpha globulin fraction on antibody formation in rabbits and mice. Proceedings of the Society for Experimental Biology and Medicine, $117,413-416$.

Starzl, T. E. (1964). Experiences in Renal Transplantation. Saunders, Philadelphia, Pennsylvania.

Starzl, T. E., Porter, K. A., Andres, G., Groth, C. G., Putnam, C. W., Penn, I., Halgrimson, C. G., Starkie, S. J., and Brettschneider,
L. (1970). Thymectomy and renal homotransplantation. Clinical and Experimental Immunology, 6, 803-814.

Stern, K. (1969). Inhibition of immune responses to sheep red cells in rats preimmunised with heterophilic antigen. Clinical and Experimental Immunology, 4, 253-264.

Stern, K., Goodman, H. S. and Berger, M. (1961). Experimental isoimmunisation to hemoantigens in man. Fournal of Immuno$\log y, 87,189-198$.

Sterzl, J. (1960). Inhibition of the inductive phase of antibody formation by 6-mercaptopurine examined by the transfer of isolated cells. Nature, $185,256-257$.

Sterzl, J. (1961). Effect of some metabolic inhibitors on antibody formation. Nature, 189, 1022-1023.

Swanson, M. A. and Schwartz, R. S. (1967). Immunosuppressive therapy: The relation between clinical response and immunological competence. New England fournal of Medicine, 277, 163170.

Tao, T. and Uhr, J. W. (1966). Capacity of pepsin-digested antibody to inhibit antibody formation. Nature, 212, 208-209.

Taylor, R. B. (1964). An effect of thymectomy on recovery from immunological paralysis. Immunology, 7, 595-602.

Terasaki, P. I., Marchiora, T. T., and Starzl, L. E. (1965). Histocompatibility Testing, ed. H. J. Winn and D. B. Amos, p. 83. Williams and Wilkins, Baltimore.

Thorbecke, G. J. and Benacerraf, B. (1967). Tolerance in adult rabbits by repeated non-immunogenic doses of bovine serumalbumin. Immunology, 13, 141-146.

Tilney, N. L. and Murray, J. (1967). The thoracic duct fistula as an adjunct to immunosuppression in human renal transplantation. Transplantation, 5, 1204-1208.

Tripathy, S. P. and Mackaness, G. B. (1969a). The effect of cytotoxic agents on the primary immune response to histeria monocytogenes. Fournal of Experimental Medicine, 130, 1-16.

Tripathy, S. P. and Mackaness, G. B. (1969b). The effect of cytotoxic agents on the passive transfer of cell-mediated immunity. fournal of Experimental Medicine, 130, 17-30.

Turk, J. L. (1964). Studies on the mechanism of action of methotrexate and cyclo-phosphamide on contact sensitivity in the guineapig. International Archives of Allergy and Applied Immunology, 24, 191-200.

Turk, J. L. and Stone, S. H. (1963). Implications of the cellular changes in lymph nodes during the development and inhibition of delayed type hypersensitivity. In Cell-bound Antibodies, ed. B Amos and H. Koprowski, pp. 51-59. Wistar Institute Press.

Turk, J. L. and Willoughby, D. A. (1967). Central and peripheral effects of anti-lymphocyte sera. Lancet, 1, 249-251.

Uhr, J. W. (1963). Actinomycin D: Its effect on antibody formation in vitro. Science, 142, 1476-1477.

Uhr, J. W. and Baumann, J B. (1961). Antibody formation. II. The specific anamnestic antibody response. Fournal of Experimental Medicine, 113, 959-970.

Unanue, E. R. and Askonas, B. A. (1967). Two functions of macrophages and their role in the immune response. fournal of the Reticuloendothelial Society, 4, 440.

Voisin, G. A., Kinsky, R. G., and Maillard, J. (1968). Demonstration d'une reactivité immunitaire specifique chez des animaux tolerants aus homogreffes. Rôle possible dans le maintien de la tolerance. In Advances in Transplantation, ed. J. Dausset, J. Hamburger, and G. Math, p. 31. Munksgaard, Copenhagen.

Waksman, B. H., Arbouys, S., and Arnason, B. G. (1961). The use of specific 'lymphocyte' antisera to inhibit hypersensitive reactions of the 'delayed' type. Fournal of Experimental Medicine, 114, 9971022.

Walker, J. G., and Siskind, G. W. (1968). Studies on the control of antibody synthesis. Effect of antibody affinity upon its ability to suppress antibody formation. Immunology, 14, 21-28.

Weigle, W. O., Nakamura, R. M., Spiegelberg, H. L., Golub, E. S., and High, G. J. (1967). Autoimmunity and termination of immunological unresponsiveness. Archives of Pathology, 84, 647658.

Weir, D. M. and Elson, C. J. (1969). Anti-tissue antibodies and immunological tolerance to self. Arthritis and Rheumatism, 12, 254-260.

Weir, D. M., Pinckard, R. N., Elson, C. J., and Suckling, D. E. (1966). Naturally occurring anti-tissue antibodies in rat sera. Clinical and Experimental Immunology, 1, 433-442. 
Werkheiser, W. C. (1963). The biochemical, cellular and pharmacological action and effects of the folic acid antagonists. Cancer Research, 23, 1277-1285.

Wheeler, G. P. (1962). Studies related to the mechanisms of action of cytoxic alkylating agents. Cancer Research, 22, 651-688.

Wheeler, G. P. (1967). Some biochemical effects of alkylating agents. Federation Proceedings, 26, 885-892.

White, R. G., Coons, A. H., and Connolly, J. M. (1955). Studies on antibody production. IV. The role of a wax fraction of mycobacterium tuberculosis in adjuvant emulsions on the production of antibody to egg albumin. Fournal of Experimental Medicine, 102, 83-103.

White, R. H. R., Cameron, J. S., and Trounce, J. R. (1966). Immunosuppressive therapy in steroid resistant proliferativeglomerulonephritis accompanied by the nephrotic syndrome. British Medical fournal, 2, 853-860.

Wiener, J., Cottrell, T. S., Margaretten, W., and Spiro, D. (1967). An electron microscopic study of steroid induced reticulo-endothelial blockade. American fournal of Pathology, 50, 187-201.

Wigzell, H. (1967). PhD thesis, Stockholm.
Wilkinson, P. C. and White, R. G. (1966). The role of mycrobacteria and silica in the immunological response of the guineapig. Immunology, 11, 229-242.

Williams, G. M., Hume, D. M., Kano, K., and Milgrom, F. (1968). Transplantation antibodies in human recipients of renal (homo) grafts. Fournal of the American Medical Association, 204, 119-122. Wilson, D. B. (1965). Quantitative studies on the behaviour of sensitised lymphocytes in vitro. II. Inhibitory influence of the immune suppressor, imuran, on the destructive reaction of sensitised lymphoid cells against homologous target cells. Fournal of $\overline{\bar{\omega}}$ Experimental Medicine, 122, 167-172.

Woodrow, J. C. (1970). Rh immunisation and its prevention. In Series Haematologica. Munksgaard, Copenhagen.

Woodruff, M. F. A. and Anderson, N. F. (1963). Effect of lympho- ڤు cyte depletion by thoracic duct fistula and administration of antilymphocytic serum on the survival of skin homografts in rats. Nature, 200, 702

Woodruff, M. F. A., Reid, B. L., and James, K. (1967). Quantitative studies with antilymphocyte antibody. Nature, 216, 758762. 